\title{
Europa w nowej ekonomii globalnej
}

\begin{abstract}
Po niemal trzydziestoletnim okresie hiperglobalizacji, od czasu światowego kryzysu finansowego z lat 2008-2009 światowy proces integracji ekonomicznej stracił impet. Niemniej, niniejszy artykuł stwierdza, że ogłaszanie śmierci globalizacji byłoby przedwczesne, natomiast proces globalizacji zmienia swój charakter. Głównymi cechami "nowej ekonomii globalnej” są: cyfryzacja, powstawanie i szybki wzrost firm "superstar", rozwój gospodarek wschodzących oraz przemiany w geografii globalnych finansów. Jednocześnie, konsekwencje dystrybucyjne zarówno hiperglobalizacji w dawnej postaci, jak i zasadniczych struktur nowej ekonomii globalnej grożą osłabianiem lub nawet utratą wsparcia politycznego dla globalizacji i wiążą się ze wzrostem fali populizmu w krajach rozwiniętych. Niniejszy artykuł uwzględnia wyzwania polityczne wyłaniające się z procesu globalizacji i na ich podstawie omawia możliwości politycznego reagowania ze strony Unii Europejskiej. Zdaniem autora, nie wystarczy skuteczne rozwiązywanie kwestii ekonomicznych i dystrybucyjnych, gdyż pilnym zadaniem dla osiągnięcia legitymizacji w Europie jest również przywrócenie równowagi i zdemokratyzowanie metod rządzenia Unią. Tylko pod tym warunkiem możliwe będzie zyskanie wiarygodności, aby móc działać w skali globalnej na rzecz kształtowania stabilnej i sprawiedliwej ekonomii globalnej.
\end{abstract}

Słowa kluczowe: cyfryzacja, firmy superstar, gospodarki wschodzące, globalne finanse, populizm, rządy europejskie.

\section{Wprowadzenie}

Globalizacja zwalnia. Towarzyszą temu nasilenie populizmu i powrót protekcjonizmu w dawnym stylu. Niniejszy artykuł jest próbą określenia najważniejszych przyczyn i objawów niedomagania globalnej integracji ekonomicznej oraz konsekwencji politycznych tego zjawiska z perspektywy europejskiej.

Od końca lat 80. XX wieku skala międzynarodowej działalności gospodarczej rosła w szybszym tempie niż produkcja globalna. Jednakże po światowym kryzysie finansowym (ŚKF) z lat 2008/2009 ta trwająca około 30 lat epoka „hiperglobalizacji” ustąpiła miejsca fazie, która bywa nazywana „nową normalnością". Jej objawami są względny zastój w handlu i napływie bezpośrednich inwestycji zagranicznych (BIZ) w stosunku do skali produkcji oraz zastój 
i postawy zachowawcze w dziedzinie transgranicznych operacji finansowych, szczególnie w bankowości (zob. rys. 1). Autor niniejszego artykułu wyznacza sobie dwa zasadnicze cele. Po pierwsze, stawia i uzasadnia tezę, że ogłaszanie śmierci globalizacji byłoby obecnie przedwczesne, stwierdzając, że proces globalizacji jedynie zmienia swój charakter. Po drugie, analizuje następstwa „nowej ekonomii globalnej”, której świadkami jesteśmy obecnie i ocenia je z punktu widzenia polityki europejskiej.

Rysunek 1. Skala działalności transgranicznej w stosunku do globalnego PKB, 1980-2017 $(1980=100)$

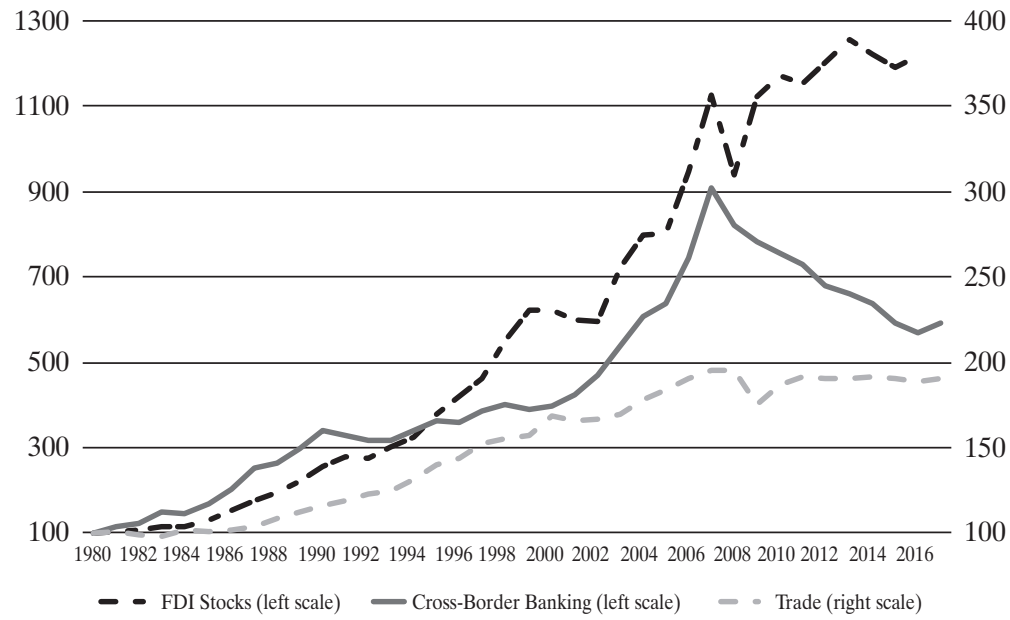

Źródło: obliczenia własne na podstawie IMF World Economic Outlook Database (PKB, Trade), UNCTAD (BIZ), i BIS Locational Banking Statistics (Cross-Border Banking).

Zasoby BIZ mierzone są jako średnia zapasów wewnętrznych i zewnętrznych. Wielkość bankowych operacji transgranicznych mierzona jest jako średnia zobowiązań i roszczeń w relacjach transgranicznych.

Podobnie jak w przeszłości, na tempo i charakter globalnej integracji ekonomicznej, a więc także na efekty tych zjawisk dla społeczeństw wpływać będą interakcje pomiędzy postępem technicznym a polityką. Z punktu widzenia techniki przemiany światowej gospodarki będą w największym stopniu kształtowane przez procesy cyfryzacji i robotyzacji - w stopniu porównywanym do wpływu, jaki w krajach rozwiniętych w latach 1870-1914 wywierał silnik parowy, a w okresie po roku 1990 - techniki informatyczne. Z punktu widzenia polityki, euforia wywołana otwarciem zachodzącym w latach 90 . XX wieku i pierwszej dekadzie nowego stulecia, uznawanym przez tzw. konsensus waszyngtoński za panaceum 
na wiele, jeśli nie wszystkie bolączki ekonomiczne (Williamson, 1990), mocno przybladła po tym, jak ŚKF ujawnił wrażliwość gospodarek ściśle powiązanych ze sobą relacjami finansowymi. Co więcej, i postęp techniczny, i globalizacja stanowią zagrożenie dla poziomu życia nie tylko ludzi o niskich kwalifikacjach: ich wpływ coraz mocniej penetruje w głąb klasy średniej. Jednocześnie ruchy populistyczne w wielu krajach rozwiniętych w coraz większym stopniu wyzwalają polityczny gniew i sprzeciw wobec globalizacji. Nową popularnością cieszy się tradycyjny protekcjonizm, wspomagany przez odradzające się podpowierzchniowo ruchy nacjonalistyczne. Uważnym obserwatorom zjawiska te niepokojąco kojarzą się z ponurym obliczem doby międzywojennej i nasilaniem postaw, które nieco później przyczyniły się do zdruzgotania światowego ładu ekonomicznego. Czy populizm i nacjonalizm powtórzą swój niszczący wpływ na światową gospodarkę? - będzie to w decydującym stopniu zależeć od tego, w jaki sposób twórcy polityki poradzą sobie z dwojakimi zagrożeniami, wynikającymi z techniki i z globalizacji.

W niniejszym artykule zbadano te kwestie z perspektywy europejskiej. W części 2 starano się ogólnie rozpoznać główne obecne i przyszłe siły sprawcze procesu globalizacji, a w szczególności określić ich wpływ na Europę. Na podstawie tej analizy, w części 3 naszkicowano związki pomiędzy globalizacją a wzrostem populizmu, znowu głównie w Europie. W części 4 omówiono dostępne na tym kontynencie opcje polityczne i poszukiwania reformy Unii Europejskiej w celu jej przygotowania na wyzwania rozwijającej się nowej ekonomii globalnej. Ostatnia, piąta część artykułu zawiera podsumowanie i wnioski.

\section{Ku nowej ekonomii globalnej}

\subsection{Powstanie globalnych łańcuchów wartości}

Od połowy lat 80 . XX wieku postępy techniczne w dziedzinie teleinformatyki oraz globalne naciski polityczne domagające się deregulacji i otwarcia gospodarek umożliwiły korporacjom szybkie globalizowanie się. Wraz z nadejściem doby CAD (projektowania komputerowego), numerycznego sterowania procesami produkcji i ogólnego komputerowego wkładu w wytwórczość nagle możliwe stało się „poszatkowanie” łańcuchów wartości. Produkcję danego produktu można było rozdzielić na szereg poszczególnych zadań w taki sposób, by następowały one niezależnie od siebie, a zarazem dokładnie pasowały do siebie, umożliwiając gładki końcowy montaż. Dzięki temu produkcja wielu towarów nie 
musiała już odbywać się w murach jednej fabryki. Te nowe możliwości podziału łańcucha wartości wykorzystywane są wszędzie tam, gdzie podział taki przynosi zysk. Naturalnie, nie przesądza to jeszcze o zasięgu takiego podziału, który może zachodzić w skali jednego kraju bądź nawet niedużego regionu. W efekcie częstym zjawiskiem stało się także zlecanie czynności produkcyjnych w ramach danego kraju. Jednakże ze względu na znacznie większe różnice w zakresie kosztów produkcji oraz wielkie zróżnicowanie kompetencji i specjalizacji w skali globalnej, globalizacja łańcuchów wartości często pozwala uzyskać o wiele większą wydajność i daje lepsze sposobności biznesowe niż stosunki czysto krajowe. To zresztą zależy od jeszcze jednego czynnika - od rozsądnych kosztów łączności i przekazu informacji. I właśnie ten czynnik odegrał kluczową rolę w okresie po roku 1990: rosnące możliwości podziału łańcuchów wartości zbiegły się z radykalnym spadkiem kosztów łączności i przekazu informacji. W efekcie łańcuchy wartości zostały nie tylko podzielone, lecz także rozrzucone po wielu dalekich krajach, dając początek temu, co z czasem nazwano globalnymi łańcuchami wartości (GŁW). Przenoszenie produkcji podzielonej na szereg czynności zachodzi na kolosalną skalę od końca lat 80., w dużym stopniu pobudzane przez BIZ. Gospodarki wschodzące, zwłaszcza w krajach Azji Południowo-Wschodniej, które szybko zrozumiały, jak wiele mogą zyskać na tych inwestycjach, otworzyły się na wymianę handlową i na BIZ i pogłębiły treść swoich regionalnych umów o wolnym handlu. Niektóre kraje, jak Chiny, wyraziły chęć przystąpienia do Światowej Organizacji Handlu (WTO). To właśnie szczególnie te kraje mogły wynieść ogromne korzyści z tego nowego rodzaju „arbitrażu pracy” poprzez uczestnictwo w globalnych łańcuchach wartości najważniejszych branż, a zwłaszcza w przemyśle odzieżowym i elektronicznym. W Europie ważnym ogniwem regionalnych sieci produkcji głównych branż przemysłowych z krajów zachodnich stały się kraje Europy Środkowej i Wschodniej (ESW), zyskując istotną rolę m.in. w przemyśle motoryzacyjnym. Z kolei na kontynencie amerykańskim meksykański przemysł Maquiladora zaczął coraz głębiej penetrować północnoamerykański łańcuch wartości.

Warto zauważyć, że globalne łańcuchy wartości są skoncentrowane regionalnie ${ }^{1}$. Na przykład, w przemyśle elektronicznym dostawcy komponentów

Odzwierciedleniem tego jest również tak zwana „,zagadka odległości” widoczna w szacunkach modeli grawitacyjnych handlu. Model grawitacyjny zakłada, że handel pomiędzy dwoma krajami jest proporcjonalny do iloczynu skali ekonomicznej tych krajów i pozostaje w zależności odwrotnej względem dzielącej je odległości geograficznej. Zagadka odległości odnosi się do stwierdzenia, wynikającego z większości badań w zakresie modeli grawitacyjnych, że w ostatnich latach skutki znacznych odległości nie tylko utrzymują się, ale wręcz nasilają - pomimo spadku kosztów transportu i łączności komputerowej. Regionalne sieci produkcji w znacznym stopniu pozwalają wyjaśnić ten dylemat. 
i półproduktów w wielu wypadkach zlokalizowani są w jednym regionie, a konkretnie we wschodniej Azji. Sytuacja taka tworzy intensywną sieć relacji handlowych w ramach danego regionu, na stosunkowo krótkie odległości, w efekcie czego regionalne umowy handlowe stają się ważnym instrumentem politycznym w promocji regionalnych klastrów. Handel nabiera charakteru naprawdę globalnego dopiero wtedy, gdy produkt końcowy zostaje dostarczony na rynek konsumencki. Podobne zjawisko zaobserwować można w europejskim przemyśle motoryzacyjnym: branża ta, szczególnie w Niemczech, wykształciła regionalne sieci produkcji, najczęściej z udziałem krajów ESW.

Od czasu światowego kryzysu finansowego tempo wzrostu handlu i inwestycji zagranicznych spada. Dlaczego globalizacja zwalnia? Czy odzyska swój impet, a jeżeli tak, to w jakiej postaci? Inaczej mówiąc, czy jesteśmy świadkami jedynie czasowego impasu, czy zasadniczej przemiany strukturalnej? Obecne spowolnienie częściowo jest konsekwencją wielkiej recesji, jaka miała miejsce po ŚKF oraz - w Europie - w szczególności po kryzysie waluty euro, odczuwalnym od roku 2010. Jako takie, wydaje się ono jedynie skutkiem tymczasowym. Spotykane są również tezy, że GŁW weszły w fazę malejących przychodów: wszystko, co dało się podzielić, już zostało podzielone. Istotnie, rozwój GŁW ostatnio wykazuje stagnację. Udział zagranicznej wartości dodanej w handlu przez dwie dekady rósł - z poziomu $24 \%$ w roku 1990 do $31 \%$ w 2010 - tymczasem przez siedem ostatnich lat zmalał do $30 \%$ w roku 2017. Należy jednak zauważyć, że w Europie udział ten nadal pozostaje bardzo wysoki, wynosząc 38\% (UNCTAD 2018).

Niemniej, spowolnienie w handlu, inwestycjach i tworzeniu GŁW może wynikać także z innych czynników technicznych, ekonomicznych i politycznych. Ażeby zrozumieć, w jakim kierunku światowa gospodarka podąży od stanu obecnego, przebadano cztery główne czynniki destabilizujące: cyfryzację, zachodzącą w związku z dalszymi postępami teleinformatyki, powstanie i gwałtowny wzrost firm typu superstar, pojawianie się coraz to nowych krajów o rynkach wschodzących i ich szybki wzrost, oraz kształtowanie się nowego wzorca finansów globalnych po ŚKF.

\subsection{Cyfryzacja}

O ile rozwijające się teleinformatyka i cyfryzacja umożliwiały podzielenie łańcucha wartości do niespotykanego wcześniej stopnia, o tyle potencjał cyfryzacji jest większy i wykracza poza samo tworzenie GŁW. Dziedzina ta zdolna jest zmieniać intensywność i charakter globalizacji poprzez takie instrumenty, jak robotyzacja, uczenie maszynowe czyli sztuczna inteligencja (AI) oraz zdol- 
ność do obniżania kosztów komunikacji osobistej poprzez zastosowanie technik rzeczywistości wirtualnej (VR) oraz rzeczywistości rozszerzonej (AR) (zob. Baldwin, 2016).

Przede wszystkim, robotyzacja z samej swojej natury nie skłania do relokowania produkcji za granicę, ponieważ procesy produkcji zrobotyzowanej można realizować równie dobrze w kraju, jak i za granicą. Różnica polega jedynie na tym, że w tym pierwszym wypadku robot zastąpi krajowe, a w drugim wypadku - zagraniczne miejsca pracy. Istotniejsze w kontekście robotyzacji jest to, w jaki sposób będzie ona wpływać na geografię globalnej produkcji. To z kolei zależeć będzie od wpływu robotyzacji na koszty produkcji. Przejście na produkcję maszynową nastąpi wtedy, gdy ceny maszyn (czyli kapitał) spadną w stosunku do kosztów pracy ludzkiej, jaką dane roboty miałyby zastąpić. W tym kontekście ważne są dwie obserwacje: po pierwsze, ceny kapitału rzeczywiście spadają (zob. np. Nordhaus, 2015), a po drugie, koszty pracy, szczególnie w gospodarkach wschodzących o szybkim tempie wzrostu, takich jak Chiny i inne kraje Azji Południowo-Wschodniej, rosną. Biorąc pod uwagę, jak wiele zadań zostało relokowanych za granicę, w dalekie regiony o niskich kosztach pracy, przemiany te mogą pobudzać relokację powrotną. Co więcej, proces taki może być wymuszany przez efekt wielkości rynku, skłaniający do przenoszenia produkcji bliżej konsumentów.

Należy pamiętać, że nawet inteligentne roboty nie są w stanie przejąć na siebie procesów produkcji w całości, a jedynie poszczególne zadania - w pierwszej kolejności te, które najłatwiej poddają się robotyzacji. W wydanym niedawno artykule Acemoglu i Restrepo (2018, s. 48) przedstawiają model automatyzacji na poziomie zadań. Badacze twierdzą, że technologiami najgroźniejszymi dla pracy ludzkiej „nie są te, które stanowią największy przełom i pozwalają wydatnie podnieść produktywność, lecz właśnie pośledniejsze - na tyle dobre, by je stosować, ale nie dość sprawne, by znacznie zwiększać produktywność". W efekcie tego relokacja zadań staje się zjawiskiem coraz bardziej rzeczywistym i to nie tylko w Europie. Marin i in. (2017) opisują zmienny wzorzec relokacji, wskazujący na to, że spowolnienie w handlu w ramach GEW następuje jako nowa postać globalizacji z firmami, które przebudowują swoje łańcuchy wartości w taki sposób, aby je skracać i nadawać im charakter bardziej lokalny lub regionalny. Autorzy ci dostrzegają też wymierne efekty relokacji i to nie tylko powodowane przenoszeniem produkcji przez firmy chińskie. W Europie zauważają oni znacznie mniejszą skalę relokacji z północnych do południowych krajów kontynentu - ruch taki zachodzi raczej w kierunku Chin i krajów ESW.

Sztuczna inteligencja (AI) jest drugim z głównych z potencjalnych czynników destabilizujących o charakterze technicznym. Uczenie maszynowe rozwija się 
szybko, powodując wręcz szokującą koncentrację regionalną - z jednej strony w Stanach Zjednoczonych, z drugiej strony w Chinach. Inaczej mówiąc, Europa jest w tych przemianach właściwie nieobecna, szczególnie w zakresie wykorzystania AI, które wymaga dostępu do olbrzymiej puli danych, by umożliwiać uczenie maszynowe. W ten sposób rolę dominującą przejmują dwa modele biznesowe: model komercjalizacji danych realizowany przez amerykańskie giganty w branży danych oraz model chiński „gromadzenia danych na szczeblu państwa”.

Trzecim potencjalnym źródłem zakłóceń i destabilizacji może być spadek kosztów bezpośredniej komunikacji osobistej (face-to-face), na co z naciskiem wskazuje Richard Baldwin (2016). Teleobecność, telekonferencje, telerobotyka, technologie VR i AR mogą obniżyć koszty, eliminując konieczność podróży. Dzięki temu kraje dotychczas słabo reprezentowane w globalizacji napędzanej przez GŁW, czyli w przemianach zachodzących przez ostatnich 30 lat, mogą zbudować nowe przewagi konkurencyjne oparte na różnicach kosztów pracy. Na dalszym etapie ewolucja ta może połączyć kraje odległe, takie jak Argentyna i odcięte od dogodnych szlaków kraje śródlądowe w Afryce i Azji, które do tej pory nie uczestniczyły w ,wielkiej konwergencji” gospodarki światowej. Taka działalność transgraniczna rozwijać się będzie nie tylko w dziedzinie handlu towarami, lecz także w handlu siłą roboczą, a więc usługami i pracą, stanowiąc nową formę globalizacji.

\subsection{Nowe firmy globalne}

Gwałtownie rozwijające się globalne, cyfrowe przedsiębiorstwa wielonarodowe (MNE), handel dobrami niematerialnymi oraz BIZ dokonywane w celach optymalizacji podatkowej zyskują na względnym znaczeniu w wymianie transgranicznej kosztem tradycyjnego handlu towarowego i BIZ lokowanymi w wytwórczość.

Handel dobrami niematerialnymi obejmuje dwa nurty - handel usługami $i$ handel wiedzą. Zaczynając od obserwacji najmniej efektownej, obecnie dobrze udokumentowany jest fakt, że ogólnie dominują BIZ w usługi - z udziałem przekraczającym $60 \%$. Wielkość ta jest zasadniczo zgodna z ogólnym udziałem usług w gospodarce światowej². Natomiast widoczna w ubiegłym wieku tendencja do lokowania BIZ w usługach przestała rosnąć po kryzysie finansowym,

2 Należy jednak zauważyć, że dane nt. udziału usług są nieco zawyżone. Według UNCTAD (2017, s. 21), „globalne BIZ w sektorze usług w znacznej części plasują się w działalności biznesowej, włącznie $\mathrm{z}$ funkcjami wykonywanymi przez firmy holdingowe $\mathrm{i}$ bazy regionalne. Działania takie są domyślnie zaliczane do usług, nawet jeżeli odnośne spółki macierzyste działają w sektorze surowcowym lub produkcyjnym". 
co może sugerować, że usługi rozwijane dzięki BIZ są często bezpośrednio powiązane z działalnością wytwórczą albo działaniami w sektorze surowcowym (zob. rys. 2). Niemniej, jako że obecnie ponad połowa wszystkich strumieni BIZ w skali globalnej trafia do krajów rozwijających się i krajów przechodzących transformację, w których udział sektora usług jest stosunkowo niski, to jest to zarazem sygnałem, że kraje te zaczynają nadganiać czołówkę w zakresie usług.

Rysunek 2. Globalne zapasy wewnętrzne BIZ z podziałem na sektory, 2001, 2007, 2015 (w bilionach dolarów)

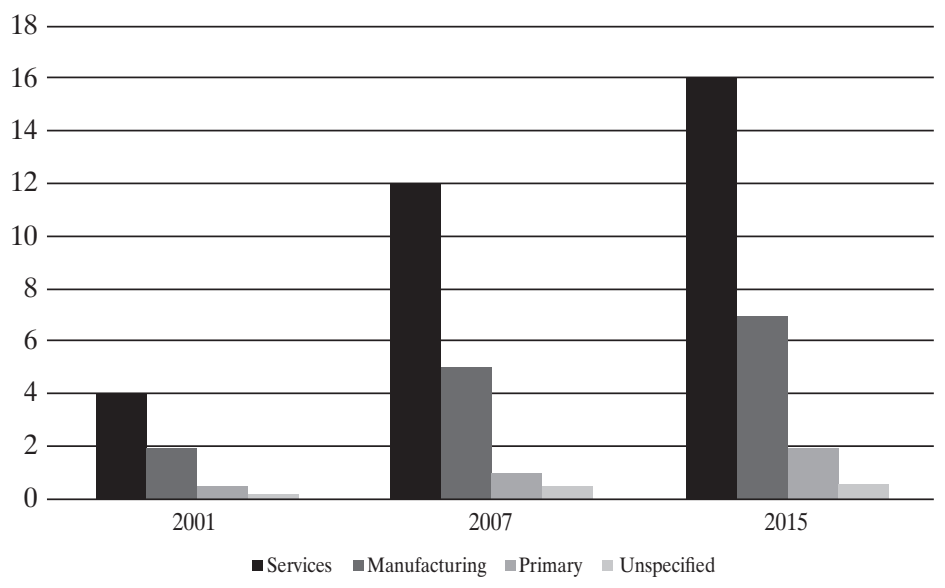

Źródło: UNCTAD, 2017, s. 21.

Przemiany strukturalne mają ostrzejszy przebieg w dziedzinie geografii wiedzy i handlu wiedzą. W przeszłości globalna pula wiedzy i technologii tradycyjnie skupiała się w krajach rozwiniętych. Ostatnio jednak wiedza w coraz większym stopniu pokonuje granice i pobudza błyskawicznie rozwijające się działania innowacyjne w gospodarkach wschodzących, w szczególności w Korei i Chinach, co dokumentuje niedawne badanie MFW oparte na statystykach patentowych (IMF, 2018). Wiedza zazwyczaj wędruje wraz z handlem, z BIZ, z migracją ludności i z innymi działaniami o charakterze transgranicznym. Oznacza to, że jej ruch jest bezpośrednio i pośrednio pobudzany przez postępy w teleinformatyce. Udział wiedzy w GLW wydaje się odgrywać ważną rolę w jej przekazie i w działalności patentowej. Autorzy badania MFW stwierdzają, że „ogólny wpływ na działalność patentową w wydaniu przeciętnych firm jest pozytywny, jako że obserwowany wzrost udziału w GŁW o 1 procent co pięć lat wyjaśnia wzrost o jedną dziesiątą w zakresie działalności patentowej przeciętnych firm w takim samym okresie" (IMF, 2018, s. 15). W oparciu o dodatkową analizę cytatów 
między patentami autorzy dokumentują także wzrost wymiany handlowej knowhow oraz rosnące znaczenie handlu wiedzą w relacjach południe-północ oraz południe-południe.

Z punktu widzenia krajów rozwiniętych, tradycyjnie utożsamianych z rozwojem innowacji, transfer wiedzy jest mieczem obosiecznym. $Z$ jednej strony sprzedaż know-how staje się coraz ważniejszym źródłem dochodów i w ten sposób przynosi bezpośrednie korzyści spółkom tworzącym innowacje. Ponadto, skoro rozpowszechniona wiedza może pobudzać produktywność w kraju odbiorcy, to może również pośrednio przekładać się na większy popyt na produkty wytwarzane przez innowacyjne firmy. Minusem jest to, że cena zapłacona za knowhow nie zawsze jest adekwatna i nie zawsze równoważy skutki późniejszego nasilenia konkurencji.

Istotą tego zagadnienia jest na dobrą sprawę stworzenie równego, uczciwego pola gry. Problem jest tutaj dwojaki. Po pierwsze, konieczna jest odpowiednia równowaga pomiędzy innowatorami a naśladowcami, po drugie zaś, co do dziś zostało już obszernie udokumentowane, handel know-how bywa często wykorzystywany w celach uchylania się od podatków metodą cen transferowych.

Wreszcie, odnośnie do nowych globalnych firm superstar w branżach cyfrowych, a zwłaszcza tak zwanej wielkiej piątki (Alphabet, Apple, Amazon, Facebook i Microsoft), nasuwa się pięć istotnych obserwacji.

Po pierwsze, firmy superstar w branży cyfrowej przeważnie działają na zasadzie „Zwycięzca bierze wszystko”. Rynki cyfrowe cechują się występowaniem silnego efektu sieciowego, a przez to także brakiem skutecznej konkurencji, co z kolei przekłada się na wyjątkowo wysokie, ponadnormatywne zyski.

Po drugie, firmy superstar są silnym czynnikiem sprawczym spadku udziału pracy w wytworzeniu produktu. Van Reenen (2018, s. 21) zauważa, że „wielkie firmy superstar będą dążyły do zapewnienia sobie wyższych marż zysku przy niższym udziale pracy w tworzeniu wartości dodanej”. To jednak nie dotyczy typowych firm amerykańskich, co wykazał autor (Sander i in., 2018). Dlatego, jak pisze dalej Van Reenen: „Tym, co wyjaśnia spadek zbiorczego udziału pracy i wzrost marż, jest realokacja w stronę firm większych i bardziej produktywnych". Inaczej mówiąc, rosnący udział firm superstar w krajowej puli wartości dodanej przesuwa dochody od siły roboczej w kierunku kapitału. Po trzecie, międzynarodowy ślad cyfrowych MNE różni się zasadniczo od śladu innych MNE, co dokumentuje UNCTAD (2017). Tabela 1 pokazuje, że tym pierwszym wystarcza ulokowanie za granicą jedynie ok. $40 \%$ łącznych aktywów własnych, aby skutecznie wejść na rynki zagraniczne i powiększyć udział sprzedaży zagranicznej w swojej sprzedaży łącznej na poziomie $70 \%$. Wynika z tego, że stosunek sprzedaży za granicę do ulokowanych za granicą aktywów jest jak 
ok. 1,8:1, czyli znacznie korzystniejszy niż stosunek 1:1 osiągany przez inne MNE. Stosunek ten jest szczególnie wysoki dla MNE będących dostawcami platform internetowych, rozwiązań cyfrowych oraz dla firm z branży informatycznej (oprogramowanie i usługi, urządzenia i komponenty do nich). W konsekwencji firmy te generują mniej inwestycji i niższe zatrudnienie w krajach, które obsługują swoimi produktami, w porównaniu do MNE z branż innych niż informatyka.

Tabela 1. Ślad międzynarodowy 100 czołowych przedsiębiorstw wielonarodowych (MNE, 2015)

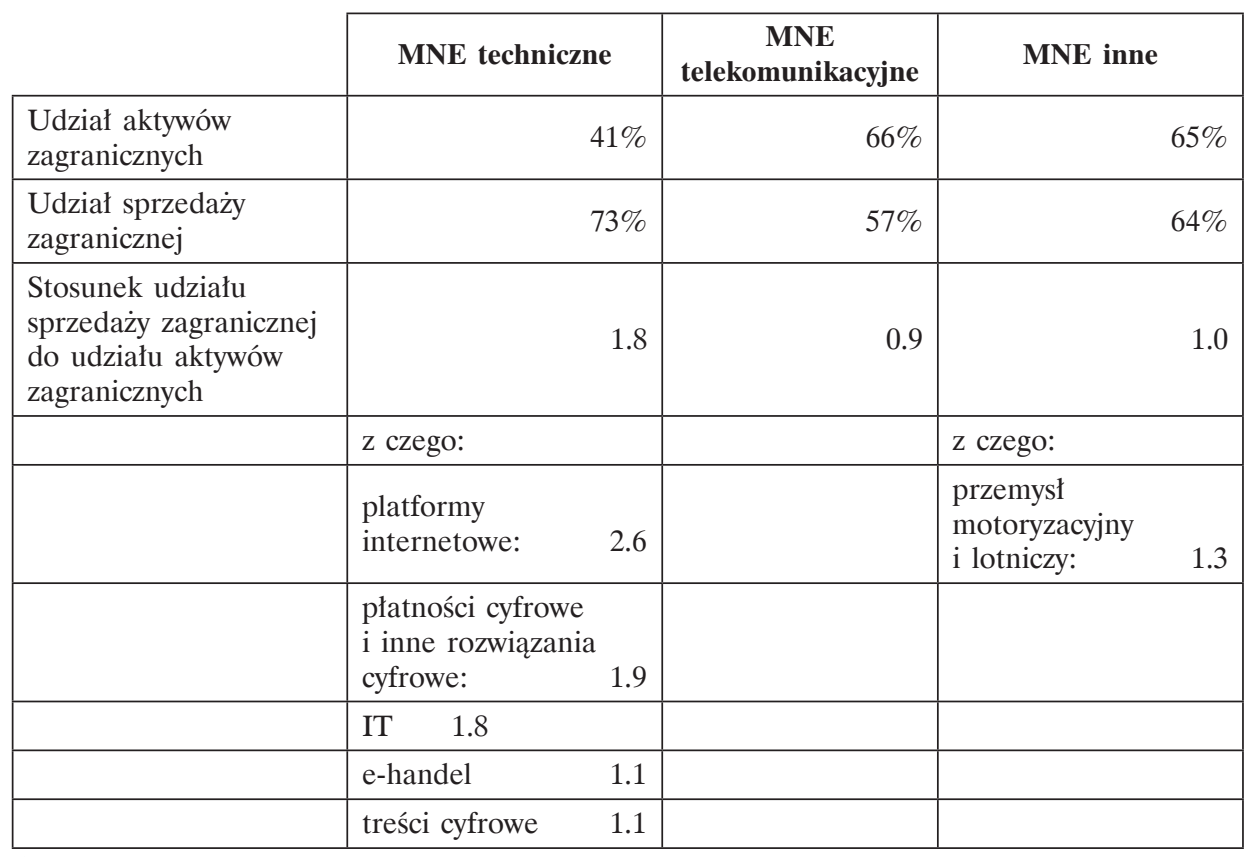

Źródło: na podstawie UNCTAD 2017, s. 170 i 171.

Po czwarte, MNE cyfrowe mają ściślejsze powiązania z macierzystymi krajami niż MNE z innych branż, a ponadto mają one swoje główne siedziby w zaledwie kilku krajach, z wyraźną koncentracją na terenie Stanów Zjednoczonych.

Po piąte, znaczna część uzyskanych za granicą dochodów, wyrażonych jako udział w łącznych dochodach przedsiębiorstwa, w wielu wypadkach nie jest ani odsyłana do kraju macierzystego, ani przeznaczana na finansowanie zdolności produkcyjnych za granicą w sposób porównywalny do tego, jak robią to MNE spoza branż technicznych (zob. tab. 2). W związku z tym UNCTAD (2017, 
s. 174) na podstawie analizy amerykańskich MNE wysuwa przypuszczenie, że: „głównym celem takiego postępowania wydaje się raczej zmniejszanie obciążeń podatkowych poprzez odraczanie (na czas nieokreślony) spłaty korekty podatku od repatriacji dochodów do Stanów Zjednoczonych. Co ciekawe, w roku 2015 MNE z branż technicznych obciążone były faktyczną stawką podatku dochodowego w wysokości $19 \%$ - znacznie niższą od stawki obowiązującej inne amerykańskie MNE. Podane tu wzorce prawdopodobnie dotyczą także MNE z branży cyfrowej - można tak zakładać, biorąc pod uwagę ich cechy wspólne z przedsiębiorstwami o profilu technicznym"3.

Tabela 2. Dochody zagraniczne a faktyczna stawka podatkowa płaconego przez MNE ze Stanów Zjednoczonych należące do pierwszej setki UNCTAD (Top100, rok 2015)

\begin{tabular}{|l|c|c|c|}
\hline & $\begin{array}{c}\text { Udział lącznych } \\
\text { dochodów zagranicznych }\end{array}$ & $\begin{array}{c}\text { Stosunek nie przekazanych } \\
\text { dochodów zagranicznych } \\
\text { do środków trwałych }\end{array}$ & $\begin{array}{c}\text { Obowiązująca } \\
\text { stawka podatkowa }\end{array}$ \\
\hline $\begin{array}{l}\text { MNE } \\
\text { techniczne }\end{array}$ & $62 \%$ & 6 & $19 \%$ \\
\hline MNE inne & $23 \%$ & 1 & $27 \%$ \\
\hline
\end{tabular}

Źródło: na podstawie UNCTAD, 2017, s. 174.

Co wszystkie omówione tendencje mają ze sobą wspólnego? Po pierwsze, handel usługami, wiedzą i produktami cyfrowymi jest domeną poważnych wypaczeń. Po drugie, zjawiska te wyraźnie wskazują na potrzebę stworzenia lub utrzymania równego, uczciwego pola gry dla handlu usługami, know-how i danymi. Strategie doganiania, strategie build-up i strategie cyfrowe są zatem zasadniczym komponentem nowej polityki przemysłowej. Kluczowym pytaniem jest to, jak pogodzić te polityki z argumentem o równym i uczciwym polu gry. Wreszcie, po trzecie, wskazują one na konieczność znalezienia środków zaradczych przeciw strategiom uchylania się od podatków. W opublikowanym niedawno studium Tørsløv, Wier i Zucman (2018) szacują, że prawie 40\% zysków przedsiębiorstw wielonarodowych jest co roku przenoszonych do krajów o niskich podatkach. Przenoszenie zysków dokonywane jest głównie metodą cen transferowych i największe rozmiary przybiera wśród amerykańskich MNE. Z kolei straty z tytułu niezrealizowanych podatków szacowane są na najwyższym poziomie w krajach Unii Europejskiej oraz w krajach rozwijających się.

3 UNCTAD zastrzega, że dane te są ściśle związane z amerykańskim systemem podatkowym i mogą się zmienić po dokonaniu zamierzonych zmian w tym systemie. 


\subsection{Kraje szybkiego wzrostu i ich wielka konwergencja}

Udział w GŁW przyniósł niejednej wschodzącej gospodarce radykalną poprawę poziomu życia obywateli i wielką redukcję skali ubóstwa. Co więcej, szybki rozwój tych krajów zmienia globalną równowagę sił ekonomicznych, co prowadzi do kształtowania się świata wielobiegunowego lub przynajmniej trójbiegunowego (zob. rys. 3). O ile pod względem obecnego kapitału wyrażonego w dolarach amerykańskich Unia Europejska i Stany Zjednoczone nadal jeszcze wyprzedzają Chiny, o tyle w kategoriach siły nabywczej świat trójbiegunowy jest już faktem.

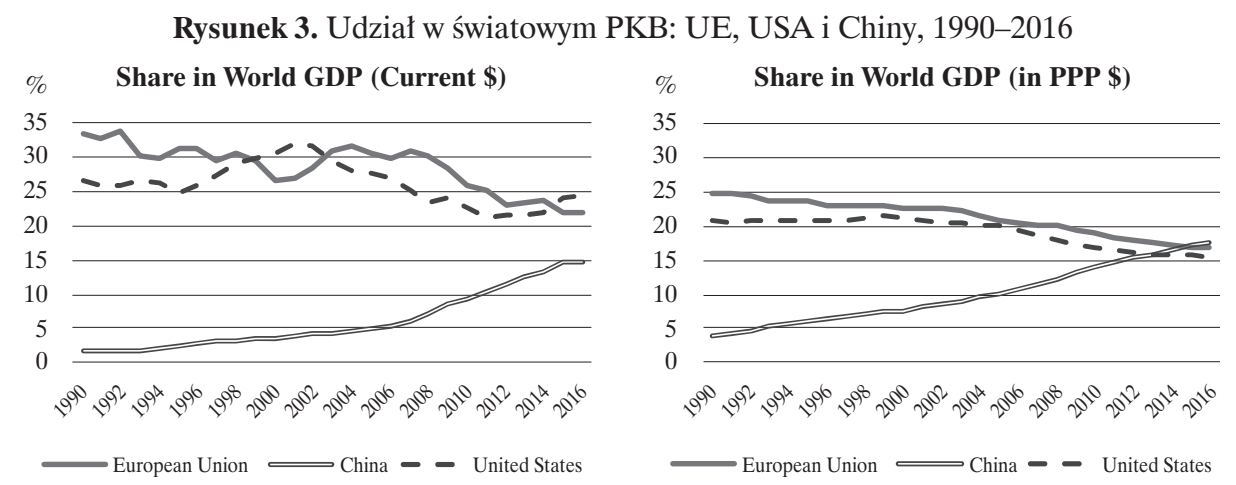

Źródło: obliczenia własne na podstawie danych Banku Światowego, World Development Indicators.

Czy „wielka konwergencja” będzie trwać dalej? I jakie będą jej następstwa dla globalnej geografii ekonomicznej? W tym kontekście rozważyć należy trzy kwestie: po pierwsze, czy znajdą się inne kraje zdolne pójść śladem modelu chińskiego; po drugie, czy w nowych technologiach kryją się nowe możliwości konwergencji dla krajów późno dołączających oraz, po trzecie, czy Chiny utrzymają tempo, które pozwala im doganiać kraje rozwinięte?

Ad 1. Czy inne kraje - w tym kontekście od razu nasuwają się Indie - okażą się następnym czynnikiem destabilizującym, po Chinach? Zacznijmy od tego, że takie kraje, jak Indie najprawdopodobniej będą się rozwijały bardziej stopniowo. Polityka przemysłowa „zza muru” w stylu chińskim nie będzie w nich równie skuteczna ani nawet równie dostępna, a to ze względu na przeszkody natury politycznej, zarówno krajowe, jak i wielostronne (WTO). Po drugie, nadzieje na relokację zadań z Chin do krajów sąsiednich o wciąż niższych kosztach produkcji mogą się nie ziścić, ponieważ odnośne zadania w Chinach mogą zostać zrobotyzowane, a nie relokowane. Na podobnej zasadzie - jak już wspomnieliśmy 
- robotyzacja ma potencjał nie tylko zastępowania relokacji, lecz nawet sprzyjania przenoszeniu działalności z powrotem do krajów, które uprzednio relokowały ją za granicę. Dlatego może się okazać, że model chiński przestanie dostarczać wzorca i recepty dla innych krajów „późno przystępujących” i nadganiających. Być może bardziej obiecującą metodą skorzystania na relokacjach pomiędzy krajami sąsiednimi będzie powiększanie skali rynku (również dzięki regionalnym umowom handlowym). Na przykład, dla spółek chińskich atrakcyjniejsze może być przenoszenie produkcji do Afryki niż do krajów ościennych, ze względu na to, że Afryka leży bliżej Europy i ma preferencyjny dostęp do rynku UE.

Ad 2. Nowe technologie, w szczególności te, których rozwój przyśpiesza dzięki redukcji kosztów komunikacji face-to-face, a więc takie jak teleobecność i telerobotyka - zgodnie z tezami Baldwina (2016). Te nowe technologie destabilizujące wzorzec mogą umożliwiać pracownikom w gospodarkach rozwijających się wykonywanie zadań o charakterze usługowym, takich jak zabiegi chirurgiczne, sterowanie robotami, konsultacje online przy użyciu technik VR i AR itd. W ten sposób kraje położone odlegle, w głębi dużych kontynentów, które w okresie ostatnich 30 lat nie korzystały z włączenia do GŁW, mogą wkrótce znaleźć swoje nowe przewagi komparatywne w dziedzinie zadań wirtualnych. „Wielka konwergencja” może postępować dalej, nawet przy destabilizujących przemianach zachodzących w sektorach usług w gospodarkach rozwiniętych.

Ad 3. Co dalej z Chinami? Jeśli przyjrzymy się integracji handlowej na szczeblu regionalnym (rys. 4), zauważymy, że integracja handlowa wykazywała największą dynamikę w Azji, a w ramach tego kontynentu szczególnie w Chinach w pierwszej dekadzie XXI wieku. Działo się tak głównie z powodu wyjątkowo silnego udziału Chin w GŁW. Obecnie wyraźnie widać, że Chiny tracą impet, przynajmniej z punktu widzenia PKB. Na to spowolnienie musiały wpłynąć trzy ważne przemiany: (1) rosnące znaczenie rynku krajowego Chin; (2) efekt „wyższych szczebli drabiny”, dzięki któremu obecnie wykonanie wielu zadań możliwe jest w samych Chinach, bez uzależnienia od importowanych półproduktów i komponentów, a zatem relokacja pracy w kierunku Chin, o czym mówiliśmy w części 2.2, oraz (3) czynnik „Made in China 2025”, czyli celowa strategia realizowana przez chiński rząd.

Ponadto, Chiny kładą silny nacisk na zdobycie przodującej pozycji technologicznej w dziedzinie odnawialnych źródeł energii oraz innych technologii i produktów przyjaznych dla środowiska, na przykład samochodów elektrycznych. Wreszcie, co wcale nie mniej ważne, chińskie podejście do kwestii technologii cyfrowych, animowane i nadzorowane przez państwo, może zapewnić branży cyfrowej w tym kraju przewagę konkurencyjną, zwłaszcza w zakresie AI, gdzie kluczem do rozwoju jest sama wielkość puli dostępnych i użytecznych danych. 
Rysunek 4. Handel towarami i usługami jako udział w PKB

(\%) w wybranych regionach 1960-2016

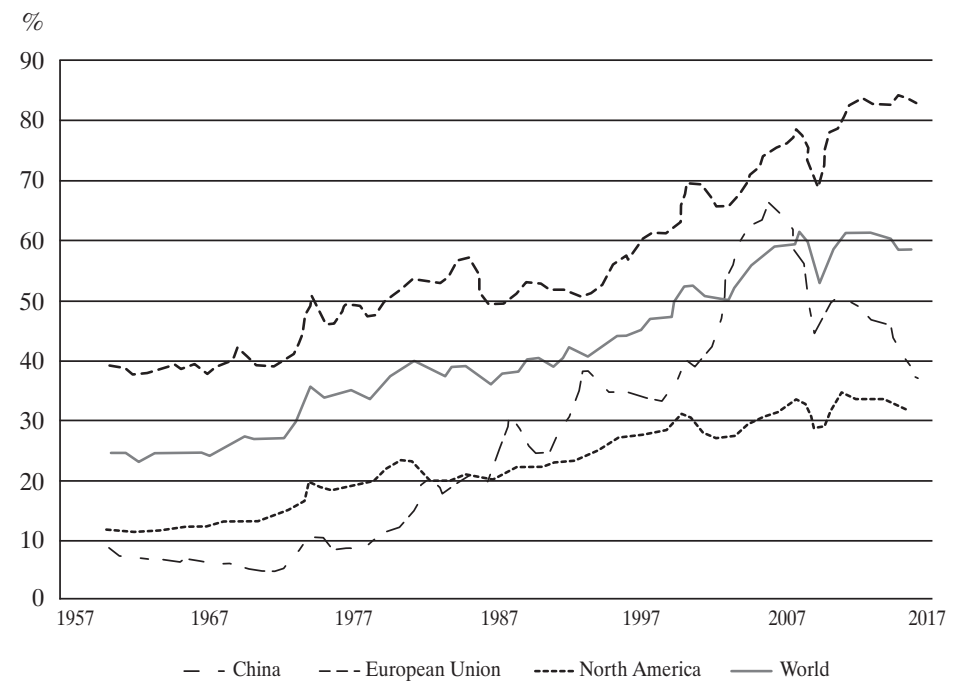

Źródło: World Bank, 2017. Pozyskano z: http://data.worldbank.org.

\subsection{Finanse globalne po światowym kryzysie finansowym}

Na pierwszy rzut oka, świadectwa empiryczne wskazują na globalną tendencję międzynarodowych finansów do okopania się na zajętych pozycjach, czyli ostrożności i oszczędzania. Bliższa analiza ujawnia dwie poważne zmiany: po pierwsze, taka redukcja kosztów w globalnej bankowości występuje w największym stopniu w Europie, a po drugie, wśród innych typów transgranicznych operacji finansowych jedyną kategorią aktywów, które rosły w stosunku do PKB w okresie po ŚKF, były BIZ. Tyle tylko, że rosły one z bardzo wyraźną koncentracją na tak zwanych centrach finansowych.

Odnośnie do globalnej bankowości, przede wszystkim zauważyć należy, że tendencję do oszczędności, okopywania się na zajętych pozycjach napędzają głównie banki europejskie. Trwałe następstwa wstrząsu, jakim był kryzys euro, nadal nieuzdrowiony system bankowy i nie w pełni ustabilizowana architektura strefy euro - w szczególności brak programu ubezpieczeniowego dla wkładów europejskich (EDIS) i ograniczony stopień dystrybucji obciążeń podatkowych - przyczyniły się do ogólnego spadku aktywności i wpływu europejskich banków, zwłaszcza w bankowości globalnej.

Dla pełnego zrozumienia przemian strukturalnych w globalnej bankowości ważne jest rozróżnienie dwóch postaci globalizacji w dziedzinie bankowości: 
z jednej strony międzynarodowego modelu biznesowego transgranicznej działalności kredytowo-depozytowej, z drugiej zaś międzynarodowego modelu tworzenia oddziałów zagranicznych poprzez BIZ (McCauley, 2011). W konsekwencji ŚKF wyhamował i zmalał głównie model międzynarodowy, przez co środek ciężkości bankowości globalnej przesunął się ku bankowości wielonarodowej. Wynika z tego, że obecna ekspozycja na zagrożenia zagraniczne jest w rzeczywistości bardziej „skonsolidowana” niż sugeruje to bilans pozycji płatniczych ${ }^{4}$. $\mathrm{Na}$ podstawie skonsolidowanych statystyk bankowych z Banku Rozrachunków Międzynarodowych (mierzonych ze względu na narodowość banków), McCauley i in. (2017) stwierdzają, że w okresie 2007-2016 postawa oszczędności i ostrego cięcia kosztów widoczna była w całej strefie euro plus Wlk. Brytania i Szwajcaria, choć wyraźny wyjątek stanowiły banki hiszpańskie. Banki amerykańskie zasadniczo utrzymały swoje operacje międzynarodowe na poziomie nie zmienionym względem lat sprzed kryzysu, a jedynie przesunęły profil działalności bardziej w kierunku modelu bankowości wielonarodowej i nieco zwiększyły ekspozycję. Stąd też następujący wniosek w pracy McCauley i in. (2017, s. 8): „Jednakże banki z pozostałej [względem Europy] części świata nadal podążały szlakiem międzynarodowej integracji finansowej (...) - instytucje japońskie, amerykańskie, kanadyjskie, australijskie oraz z rynków wschodzących powiększały skalę swoich roszczeń zagranicznych na całym świecie, częściowo kompensując $\mathrm{w}$ ten sposób odwrót banków europejskich. W tym sensie tendencja ku deglobalizacji nie zyskała szerokiego oparcia”. Warto zauważyć, że rosnąca obecność gospodarek wschodzących w bankowości globalnej zapewne pozostaje niedoszacowana, jako że wiele z nich nie raportuje do Banku Rozrachunków Międzynarodowych lub - jak Chiny - czyni to dopiero od niedawna. W każdym razie pierwsze analizy wykazują, że banki z rynków wschodzących w szybkim tempie dołączają do globalnych rynków bankowych i że w największym stopniu dotyczy to banków chińskich.

Przechodząc do bezpośrednich inwestycji transgranicznych, odporności BIZ na kryzys finansowy nie należy traktować jako faktu zupełnie zaskakującego. Owszem, zostało dobrze udokumentowane, że w obrazie następstw kryzysu finansowego BIZ okazały się znacznie stabilniejszym źródłem finansowania zagranicznego niż strumienie bankowe lub portfelowe. Działo się tak w niemałym stopniu dlatego, że kryzysy finansowe mają tendencję zbiegać się z kryzysami

4 Raporty Banku Rozrachunków Międzynarodowych podają dane statystyczne na temat bankowości światowej na podstawie skonsolidowanej i lokalizacyjnej. W statystykach skonsolidowanych banki klasyfikuje się według ich narodowości, podczas gdy w statystykach lokalizacyjnych klasyfikuje się je według usytuowania siedziby, podobnie jak w statystykach bilansów płatniczych. 
walutowymi, a duża dewaluacja zwiększa konkurencyjność cenową gospodarki w kryzysie. Jednak w odniesieniu do globalnego kryzysu finansowego takie wyjaśnienie wydaje się niewystarczające. Lane i Milesi-Ferretti (2016) przedstawili gruntowne badanie na temat pokryzysowych tendencji ku integracji finansowej i wykryli ponad proporcjonalną rolę „,entrów finansowych” w BIZ - rolę, która po ŚKF jeszcze się zwiększyła. Wzrost skali BIZ w okresie pokryzysowym da się w dużej mierze wyjaśnić wzrostem pozycji BIZ w tych jurysdykcjach.

Czym są wspominane „centra finansowe” i o jakiego rodzaju BIZ mówimy? Lane i Milesi-Ferretti wybierają centra finansowe na podstawie ich nadzwyczaj wysokich wskaźników aktywów zewnętrznych oraz pasywów w stosunku do PKB, w porównaniu z resztą świata. Oprócz dobrze znanych małych centrów finansowych (takich jak Bermudy lub Kajmany) do kategorii tej zalicza się także szereg gospodarek rozwiniętych, zwłaszcza Belgię, Hongkong, Irlandię, Luksemburg, Holandię, Singapur, Szwajcarię i Wielką Brytanię. W następstwie ŚKF w tej grupie krajów nastąpiło gwałtowne zmniejszenie skali transgranicznych operacji bankowych. Jednocześnie nastąpił drastyczny wzrost poziomu roszczeń i zobowiązań BIZ. Jakie są główne czynniki sprawcze tej dynamiki BIZ?

Zacznijmy od tego, że większe kraje z tej grupy są siedzibami wielkich przedsiębiorstw wielonarodowych. Dlatego kiedy poziom działalności w zakresie BIZ ogólnie wzrasta, rośnie również poziom BIZ w tych krajach. To jednak nie wystarcza do wyjaśnienia zarówno koncentracji BIZ w tych krajach, jak i ogromnych przesunięć BIZ w stronę centrów finansowych. Lane i MilesiFerretti (2017, s. 14) raportują: „Na koniec roku 2007 rezydenci centrów finansowych posiadali około 43 procent wszystkich zagranicznych roszczeń BIZ na świecie, natomiast BIZ w centrach finansowych stanowiły około 40 procent łącznej puli światowej BIZ. Do końca roku 2014 roszczenia BIZ ze strony centrów finansowych wzrosły do połowy łącznej puli globalnej, a zobowiązania do poziomu 44 procent". Następnie badacze ci diagnozują dwa główne czynniki mogące wyjaśniać rozmiary niedawnej dynamiki pozycji BIZ w centrach finansowych.

Po pierwsze, autorzy ci wskazują na rosnące znaczenie tak zwanych „podmiotów specjalnego przeznaczenia”. Są to podmioty prawne stworzone przez swoje spółki macierzyste usytuowane w innych jurysdykcjach. Celem istnienia takich podmiotów nie jest prowadzenie żadnej działalności produkcyjnej. Tworzone są one po to, by zdobywać i pomnażać kapitał albo utrzymywać aktywa i/lub pasywa. Wprawdzie dane na temat takich spółek nie są łatwo dostępne, jednak udokumentowano, że ponad $75 \%$ wszystkich roszczeń i zobowiązań BIZ w Holandii powiązana jest właśnie z takimi podmiotami. Dla Luksemburga odnośna wielkość jest jeszcze wyższa i przekracza $90 \%$. 
Po drugie, autorzy informują o rosnącej skłonności MNE do przenoszenia swoich siedzib do centrów finansowych. W sytuacji, w której przeniesiona zostaje tylko oficjalna siedziba, a nie zakłady produkcyjne, te ostatnie i tak zaliczają się do puli BIZ centrum finansowego. To właśnie w ten sposób znane raje podatkowe, takie jak Irlandia, zdołały zwiększyć skalę wykazanych roszczeń BIZ o 600 mld dolarów w latach 2007-2014, podnosząc roszczenia BIZ na poziom, który przekracza wielkość PKB Irlandii o czynnik wyższy niż 5 .

Podsumowując, globalne finanse po ŚKF charakteryzuje: 1) słabość bankowości europejskiej; 2) przesunięcie ku bankowości wielonarodowej; 3) postępująca globalizacja banków wywodzących się z gospodarek wschodzących, a zwłaszcza $\mathrm{z}$ Chin oraz 4) przesunięcie BIZ w stronę centrów finansowych, które następuje z przyczyn innych niż produkcja, co sugeruje, że „poważną rolę w tych zjawiskach odgrywa rosnąca złożoność struktury przedsiębiorczej wielkich korporacji międzynarodowych" (Lane i Milesi-Ferretti, 2017, s. 5).

\section{Globalizacja i populistyczny gniew}

Zarówno Europa, jak i Stany Zjednoczone doświadczają fali populizmu, który - zwłaszcza w wypadku USA - powoduje przywrócenie na arenie politycznej postaw protekcjonistycznych w dawnym, tradycyjnym wydaniu. Przemiany takie zagrażają wielostronnemu podejściu do zjawiska globalizacji, jakie dominuje w powojennych stosunkach międzynarodowych. Dla naszych rozważań istotą sprawy jest pytanie, w jakim stopniu źródła eksplozji populizmu da się powiązać przyczynowo z wstrząsami ekonomicznymi, których źródłem lub przekaźnikiem jest globalizacja.

W wydanym niedawno stadium historycznym Eichengreen (2018) rozważa: „Przytoczona tutaj historia sugeruje, że populizm uruchamiany jest przez połączenie niepewności ekonomicznej, zagrożenia dla tożsamości narodowej i niewrażliwego ustroju politycznego, ale że można go tłumić poprzez reformy gospodarcze i polityczne pozwalające rozwiać obawy niezadowolonych”. Przytaczany badacz przechodzi następnie do zdefiniowania populizmu jako ruchu politycznego, który przejawia tendencje antyelitarne, autorytarne i natywistyczne (antyimigracyjne). Sformułowana w ten sposób definicja obejmuje zarówno populizm

5 Lane i Milesi-Ferretti (2017) przypominają, że w sytuacji, w której udziałowcy MNE relokowanych do kraju pochodzenia nie zmieniają się, to portfolio zobowiązań z tytułu akcji wzrasta o taką samą kwotę, w efekcie czego bilans na koncie kapitałowym pozostaje bez zmian. 
lewicowy, w którym dominuje element antyelitarny, jak i populizm prawicowy, skłonny za wszystkie trudności i problemy winić „obcych”.

W dyskusjach na temat ostatniej fali populizmu rozróżnić można dwa obozy intelektualne, które z całą stanowczością podają różne źródła i powody tego ruchu. Jeden z nich koncentruje się na roli ekonomii, a zwłaszcza na wzroście niepewności ekonomicznej, jaką sprowadza globalizacja, szczególnie w okresie po ŚKF, drugi natomiast skupia się bardziej na „reakcji i kontestacji kulturowej”. Historyczny punkt widzenia Eichengreena pozwala połączyć obie te perspektywy, ale zarazem kładzie wyraźny nacisk na odpowiedzialność „niewrażliwego ustroju politycznego".

Aby przeanalizować rolę globalizacji we wzbudzeniu fali populizmu, w pierwszej kolejności zajęto się efektem dystrybucyjnym globalizacji, by następnie omówić zauważalną w ostatnim okresie niewrażliwość, czyli nieczułość ustrojów politycznych i na koniec ocenić związek przyczynowy pomiędzy globalizacją i populizmem.

\subsection{Globalizacja i niezadowoleni}

Globalizacja, a w szczególności wstrząs chiński, mają zarówno aspekty pozytywne, jak i negatywne. Oprócz typowych korzyści z wymiany handlowej, to znaczy niższych cen towarów, w których wykorzystano tańsze surowce pochodzące zza granicy, uczestnictwo w GLW może wywierać korzystny wpływ na produktywność siły roboczej, podnosząc tym samym międzynarodową konkurencyjność firm krajowych. Według Constantinescu i in. (2017), wzrost udziału w GLW o $10 \%$ podnosi średnią produktywność siły roboczej o 1,7\%.

Jednakże zwiększona globalizacja łańcuchów wartości wymaga również dokonania w krajach rozwiniętych restrukturyzacji na wielką skalę i pociąga za sobą problemy tych, którzy tracą miejsca pracy wskutek relokacji zadań do odległych krajów. Obecnie jest dobrze udokumentowane, że od lat dziewięćdziesiątych XX wieku globalny rozkład dochodów uległ kolosalnym zmianom. Zebrane świadectwa wskazują na dwa główne czynniki sprawcze rozbicia dawnych wzorców dystrybucji. Pierwszym są poważne skutki redystrybucyjne zarówno pomiędzy poszczególnymi krajami, jak i wewnątrz nich w kategoriach warstw dochodu. Drugim - wyraźny spadek udziału dochodów z pracy względem udziału dochodów odpływających do kapitału.

Skutki redystrybucyjne są obecnie spektakularnie uwidocznione w postaci głośnej „krzywej słonia” (Elephant Curve; Lakner i Milavonic, 2013). Wykres ten ilustruje wzrost dochodu na głowę wyrażony w percentylach dystrybucji dochodu globalnego, od 5\% najuboższych krajów po lewej stronie do 1\% naj- 
bogatszych po prawej. W okresie 1988-2008 dochody per capita wzrosły średnio o około $24 \%$ (czyli ok. 1,1\% rocznie). Widać wyraźnie, że 5\% najuboższych krajów nie w pełni korzystało $\mathrm{z}$ tego wzrostu, natomiast warstwy średniego dochodu w gospodarkach wschodzących skorzystały z niego wydatnie, czego efektem było wywindowanie dużych grup ludności ponad poziom ubóstwa. Nierówności pomiędzy krajami zmniejszały się - Baldwin (2016) nazwał ten proces „wielką konwergencją". W krajach rozwiniętych głównym powodem do obaw są przemiany zachodzące w górnych $20 \%$ percentyli: „krzywa słonia” wykazuje niemalże stagnację dochodów na głowę dla grupy $80-90$ percentylu oraz słabe wyniki niemal wszystkich z wyjątkiem szczytowego $1 \%$. Zjawisko to często bywa interpretowane jako dowód na zapaść klasy średniej w krajach rozwiniętych, której towarzyszy kolosalny wzrost dochodów gromadzonych przez niezwykle wąską elitę. Biorąc pod uwagę, że przemiany te nastąpiły równocześnie $\mathrm{z}$ wielkim rozwojem globalizacji, trudno się dziwić, że dostrzega się powiązanie pomiędzy utratą dobrze płatnych miejsc pracy (w produkcji) w krajach zamożnych a gwałtownym rozwojem konkurencji w gospodarkach wschodzących.

Jednakże zbieżność tego zjawiska $\mathrm{z}$ hiperglobalizacją i rozwojem GŁW nie ma charakteru związku przyczynowego. Jak już mówiono, odpowiedzialność za utratę miejsc pracy i dochodów (w szczególności przez gorzej wykwalifikowanych pracowników w krajach rozwiniętych) w dużej mierze ponoszą nowe technologie i powstanie cyfrowych firm superstar. Niedawne badanie MFW (IMF, 2017) analizuje przyczyny powszechnego spadku udziału pracy w dochodach. Jego autorzy raportują, że w krajach rozwiniętych udział pracy w dochodach zmniejszył się w latach 1993-2014 o prawie cztery punkty procentowe. Spadek ten przypisywany jest $\mathrm{w}$ około połowie postępom techniki, natomiast udział w GEW oraz integracja finansowa odegrały tu znacznie mniejszą rolę. W tym samym studium prześwietlono także wpływ przemian na ludzi ze względu na poziom ich kwalifikacji. Analiza ta ujawnia silne efekty redystrybucyjne zachodzące w całym spektrum: wysoko wykwalifikowani zyskują więcej, a nisko wykwalifikowani tracą więcej, podczas gdy sytuacja grup pośrednich zmienia się mniej wyraźnie. O ile w odniesieniu do grup wysoko i nisko wykwalifikowanych procesy te można by jedynie w małym stopniu tłumaczyć wpływem technologii lub uczestnictwa w GEW, to w wypadku grupy pracowników o średnich kwa-

6 Przeciwnie dzieje się na rynkach wschodzących, gdzie powodem spadku udziału pracy w dochodach o prawie 6 pkt procentowych jest w decydującym stopniu uczestnictwo w GLW, podczas, gdy nowe technologie odgrywają pod tym względem małą rolę. Trzeba jednak zauważyć, że mówimy tutaj o udziale w dochodach, a nie o całkowitej wielkości dochodów. Ponieważ w wielu gospodarkach wschodzących, a zwłaszcza w Chinach, dochody rosły gwałtownie, dochody z pracy w sumie nadal się zwiększają, tyle tylko, że nie tak spektakularnie jak dochody z kapitału. 
lifikacjach z pewnością jest inaczej. Ci ludzie stracili poważną część swojego udziału w dochodach właśnie z powodu postępu technicznego i uczestnictwa w GŁW. Co więcej, w krajach rozwiniętych technologia była jeszcze ważniejszym czynnikiem w „drążeniu i drenowaniu klasy średniej”. Zgodnie z wnioskami wcześniej przywołanego studium Acemoglu i Restrepo (2018), efekt taki da się łatwo pogodzić z efektami automatyzacji zadań, co przy okazji wskazuje na poważną rolę robotyzacji.

$\mathrm{Z}$ tych zjawisk można wnioskować, że wynikający z globalizacji rozdział zysków wśród pracowników w świecie uprzemysłowionym zmienia się i w coraz większym stopniu preferuje osoby wysoko wykwalifikowane. Ponadto, w miarę, jak rośnie udział kapitału w dochodach, beneficjentem niezmiernych korzyści stają się globalne korporacje.

Opisywana sytuacja zaostrzyła się po tym, jak ŚKF zepchnął w szczególności kraje rozwinięte w długotrwałą recesję, która dotknęła Stany Zjednoczone i Europę. W Europie, a zwłaszcza w strefie euro, sytuację dodatkowo pogorszył kryzys strefy euro, który nastąpił wkrótce później. O ile w gospodarce wysokociśnieniowej skutki uboczne przemian strukturalnych bywają znacznie łatwiej amortyzowane przez wzrost możliwości zatrudnienia, to taki podwójny wstrząs globalizacji i kryzysów finansowych wyraźnie przekłada się na głębokie i trwałe następstwa w zakresie dochodów i bezpieczeństwa ekonomicznego dużych grup ludności.

Podsumowując, określiliśmy trzy najważniejsze czynniki sprawcze niepewności ekonomicznej: uczestnictwo w GLW i relokację miejsc pracy; postęp techniczny wraz z robotyzacją i cyfryzacją oraz kryzysy finansowe.

\subsection{Wrażliwość i zdolności reagowania systemów politycznych}

Jeśli historia może być tutaj wskazówką, fali populizmu można spodziewać się wtedy, gdy ustrój polityczny jest nieczuły i niereagujący (Eichengreen, 2018), a w ujęciu pozytywnym, populizm można kontrolować poprzez punktualne, właściwe i proporcjonalne reakcje polityczne. Skoro tak, to co wstrzymuje takie reakcje?

Po piewsze, klasyczny argument ekonomistów, mówiący, że przegranych na globalizacji można wynagrodzić, bo pozwolą na to łączne korzyści z wymiany handlowej, jest zasadniczo słuszny, lecz niestety wyłącznie jako możliwość teoretyczna. W praktyce ostatnich dziesięcioleci globalne korporacje skwapliwie wykorzystywały sposobności uchylania się od płacenia podatków, jakie otwiera zglobalizowany świat inwestycji, a wygrani na globalizacji głosowali i lobbowali raczej na rzecz obniżania podatków niż na rzecz redystrybucji rosnących docho- 
dów, mogącej przywrócić przegranym utracone możliwości pracy zarobkowej. Jednocześnie zaś kryzys finansowy oraz wielka recesja, która po nim nastąpiła, radykalnie pogorszyły szanse przegranych procesu globalizacji na znalezienie nowego zatrudnienia.

Po drugie, reakcje polityczne zależą od woli politycznej - od decyzji i wyborów. Oczywiście, niektóre kultury są mniej skłonne do amortyzowania skutków przemian strukturalnych narzędziami polityki socjalnej i polityki zatrudnienia, a inne bardziej. W tym kontekście wystarczy pomyśleć o Stanach Zjednoczonych w porównaniu z Europą, a w jej ramach szczególnie o krajach skandynawskich $\mathrm{z}$ ich hojnymi systemami podtrzymania dobrobytu i zabezpieczenia społecznego.

Po trzecie, adekwatne reakcje polityczne mogą być też ograniczane przez wielkość dostępnych zasobów w stosunku do skali nietypowego wstrząsu ekonomicznego. Wstrząs globalizacyjny może być tak wielki, że środki przeznaczane na „rekompensaty dla przegranych” bywają ograniczone wysokością wpływów podatkowych, np. skalą dochodów, których fiskus nie zrealizował z winy skutecznych strategii uchylania się od podatków przez wielkie korporacje wielonarodowe. Albo odwrotnie, wstrząsy wywołane przez kryzys finansowy mogą być tak dramatyczne - przykładem ŚKF - że nawet interwencje polityczne na dużą skalę nie wystarczają i nie chronią przed głęboką i długotrwałą recesją.

Po czwarte, pewne ramy instytucjonalne, takie jak przepisy podatkowe ograniczające deficyty fiskalne, mogą stanowić „polityczny kaftan bezpieczeństwa”. Tak właśnie dzieje się w widoczny sposób w krajach strefy euro. Kraje członkowskie UGW (Unii Gospodarczej i Walutowej) nie są w stanie reagować na niespodziewany i nieregularny wstrząs ani instrumentami krajowej polityki monetarnej, ani dewaluacją waluty7. Co gorsza, polityka fiskalna w wielu państwach członkowskich została poważnie skrępowana przepisami skarbowymi Europejskiego Paktu Stabilności i Wzrostu.

Wreszcie, pewną rolę może także odgrywać ideologia i brak solidarności międzynarodowej. W strefie euro twórcy polityki postawili w największym stopniu na liberalizację rynku pracy i w ten sposób usiłowali wytłumić wstrząsy wywołane przez globalizacje i kryzys finansowy. Podczas kryzysu strefy euro brak mechanizmów transgranicznych transferów fiskalnych oraz niechęć krajów-wierzycieli do przyjmowania z zagranicy odpowiedniej porcji obciążenia ukierunkowały pakiety ratunkowe w stronę polityki oszczędności i wyrzeczeń w połączeniu z reformami strukturalnymi obliczonymi na wywołanie korekt wynagrodzeń

7 Ponieważ kryzys finansowy roku 2008 był wstrząsem doświadczanym wspólnie przez wszystkie kraje członkowskie, ten argument miał zapewne mniejsze znaczenie (chociaż adekwatność ówczesnych reakcji ze strony polityki monetarnej EBC jest dyskusyjna) niż podczas kryzysu w strefie euro, który zaczął się w roku 2010 i uderzył w kraje członkowskie asymetrycznie. 
i cen w dół. Większość obserwatorów z kręgów akademickich zgadza się, że taka reakcja polityczna poważne pogłębiła i przedłużyła kryzys w wielu dotkniętych kryzysem krajach Europy, szczególnie na południu kontynentu.

\subsection{Globalizacja, kryzys finansowy i nasilenie populizmu}

Podsumowując to wszystko, możemy udokumentować narastającą niepewność ekonomiczną w wielu krajach rozwiniętych, odczuwaną w największej mierze przez osoby o niskich kwalifikacjach, ale coraz wyraźniej zagrażająca także klasie średniej. Natomiast trudno byłoby wskazać jedną konkretną przyczynę lub choćby głównego winnego tego stanu. Społeczeństwa stojące w obliczu złożonych zagrożeń dla swojego poziomu życia i bezpieczeństwa ekonomicznego widzą niewrażliwość polityki i szukają kozłów ofiarnych. Zależnie od zaplecza ideologicznego, edukacyjnego i kulturalnego ludzi, jako winnych wskazuje się różne grupy: populiści prawicowi na ogół obwiniają „obcych” - imigrantów, konkurencję zagraniczną itd., podczas gdy populiści z lewicy oskarżają „elity”. Oczywiście populistyczni „przedsiębiorcy polityczni” objaśniają świat w sposób uproszczony i podają niezadowolonym proste recepty na to, jak ulżyć ich doli.

Co prawda pewne świadectwa wskazują na słuszność hipotezy kulturowej, szczególnie w zakresie ścierania się populizmu lewicowego i prawicowego, jednak przeprowadzone ostatnio gruntowne badanie wykryło, że głównym źródłem narastania fali populizmu jest nasilona postrzegana i uświadamiana niepewność ekonomiczna. W skupionym na sprawach europejskim studium Guiso i in. (2018) badają, w jaki sposób rozkład głosów oddanych na partie populistyczne w różnych regionach Europy odzwierciedla reakcję na: 1) „wstrząs globalizacji” (czyli „efekt Chin”) oraz 2) na europejski kryzys finansowy lat 2008-2013. Europa stanowi naturalny poligon doświadczalny do rozpoznawania źródeł populizmu, ponieważ „wstrząs chiński” wywarł inne skutki w Europie Zachodniej, inne zaś - w Europie Wschodniej. Na zachodzie kontynentu dominował odpływ zadań i miejsc pracy za granicę, natomiast kraje Europy Wschodniej były częściowo również odbiorcą zadań i miejsc pracy relokowanych z zachodu. $\mathrm{Z}$ drugiej strony, kraje członkowskie strefy euro skrępowane były ciasnym politycznym kaftanem bezpieczeństwa (zależnym od względnej kondycji ekonomicznej i fiskalnej danego kraju w chwili nadejścia nieregularnych wstrząsów), podczas gdy kraje nie członkowskie były wolne od takich ograniczeń.

Guiso i in. (2018) wykorzystują tę właśnie perspektywę, aby pokazać, że wstrząs globalizacji, który dotknął regiony Europy Wschodniej najbardziej narażone na globalizację, nie sprzyjał pojawianiu się ani wzmacnianiu głosów 
populistycznych. W Europie Zachodniej, przeciwnie, wstrząs globalizacji wywołał wielkie pomnożenie głosów oddanych na partie populistyczne. Świadectwo takie sugeruje, że w kontekście głosowania na populistów istotnym czynnikiem jest podział na wygranych i przegranych globalizacji. Co więcej, autorzy ci wskazują również, że w tych krajach Europy Zachodniej, które należą do strefy euro, efekt kaftana bezpieczeństwa wyjaśnia aż w trzech czwartych zwiększone powodzenie wyborcze partii populistycznych w porównaniu z krajami spoza strefy euro. Inaczej mówiąc, im bardziej ograniczona swoboda państw w zakresie podejmowania środków naprawczych po wstrząsach globalizacji i kryzysach finansowych, tym większe poparcie polityczne dla partii populistycznych. Dlatego Guiso i in. (2018, s. 4-5) twierdzą, że „Bunt kulturalny przeciw globalizacji, tradycyjnej polityce i instytucjom, a także przeciw imigracji i automatyzacji, nie może być zjawiskiem egzogenicznym, lecz napędzany jest niezadowoleniem i lękiem o podłożu ekonomicznym".

Na podobnej zasadzie, w studium historycznym na temat wpływu kryzysów finansowych na zachowania wyborców i sukcesy politycznych ekstremistów w długim okresie od roku 1870 do 2014, Funke i in. (2015) dowodzą, że recesje wywołane kryzysami finansowymi zwiększają pulę głosów oddawanych na partie skrajnie prawicowe o około $30 \%$. Z drugiej strony, badacze ci nie byli w stanie wykazać analogicznego wpływu zwyczajnych recesji gospodarczych ani innych wstrząsów makroekonomicznych. Autorzy wnioskują z tego, że opinia publiczna ma większą tendencję uznawać, że to kryzysy finansowe, a nie „zwyczajne” kryzysy są konsekwencją błędów i zaniedbań politycznych, o które obwiniać należy tradycyjne elity polityczne. Co więcej, badacze ci podkreślają fakt, że pokonywanie kryzysów finansowych często wymaga niepopularnych akcji ratunkowych i oddłużeniowych na rzecz przedsiębiorstw zagrożonych upadłością, co opinia publiczna uznaje za nagradzanie tych, którzy w największym stopniu przyczynili się do wywołania kryzysu. Wreszcie, reperkusje społeczne kryzysu finansowego na ogół sięgają głębiej i trwają dłużej niż w wypadku zwyczajnych kryzysów.

Podsumowując, wymieńmy raz jeszcze co stanowiło podłoże, na którym populiści z łatwością budowali swoje autorytarne, upraszczające diagnozy i recepty, chętniej oskarżając kozły ofiarne niż podejmując i usiłując rozwiązać prawdziwe problemy. Na podłoże to składały się: pęknięcia społeczne zlekceważone przez politykę państwa, rosnące obawy wywołane wstrząsami globalizacji i kryzysów finansowych, niestabilny i przez to podatny na kryzysy system globalny, regionalny i finansowy, a równocześnie - o czym na porządku dziennym informowały media - gigantyczne fortuny i zyski jednego procenta najbogatszych oraz korporacji, skutecznie uchylających się od płacenia podatków. 


\section{Opcje polityczne w Europie w ramach nowej ekonomii globalnej}

Wśród czynników kształtujących przyszłość Europy z pewnością znajdą się następstwa nowego wcielenia globalizacji i polityczne reakcje na nią. Wnioski z zawartych powyżej rozważań przekonują, że globalizacja nie jest procesem zdolnym samoczynnie podtrzymywać swój rozwój. Gdyby nie zarządzać globalizacją i jej konsekwencjami dystrybucyjnymi, proces ten przejawi tendencje do podważania własnych podstaw, czyli wiary w wolne, otwarte rynki, społeczeństwa i granice.

Dla Europy otwarte rynki zarówno w ramach UE, jak i wobec reszty świata, są niezbędnym warunkiem jej modelu sukcesu ekonomicznego. Dlatego zapewnienie trwałości globalizacji leży w żywotnym i długofalowym interesie Europy. Aby było to możliwe, konieczne jest spełnienie szeregu warunków, od zachowania wrażliwości i uwagi społecznej, po podjęcie zdecydowanych działań politycznych. Potencjalna lista zadań do wykonania jest długa i można ją znaleźć na stronach internetowych wielu inicjatyw, zespołów eksperckich i doradczych oraz dyrekcji unijnych. Obejmuje ona i obraca się wokół takich zagadnień, jak cyfryzacja, populizm, nierówności, konkurencyjność i inne. Jednak zestawienie listy to nie wszystko; warunkiem adekwatnej reakcji politycznej jest rozwiązanie trudnej kwestii rozdysponowania zadań. Na jakim szczeblu winny one być realizowane? Na krajowym, europejskim czy globalnym? W dalszej części niniejszego studium najpierw omówione zostaną najpilniejsze kwestie polityczne, a w dalszej kolejności problem rządów.

\subsection{Obszary reakcji politycznych}

W swoim wystąpieniu na Sympozjum Polityki Ekonomicznej Banku Rezerwy Federalnej Kansas City w Jackson Hole, w roku 2017, Prezydent EBC Mario Draghi stwierdzit: „Ludzie niepokoją się o to, czy otwartość jest uczciwa, czy jest bezpieczna i czy jest sprawiedliwa".

By rozważyć na początek kwestię sprawiedliwości, ekonomiści handlu w zasadzie zgadzają się co do tego, że po otwarciu się na wymianę handlową w społeczeństwie rysuje się podział na wygranych i przegranych. Jako, że korzyści netto z handlu są znaczne i stanowią silny argument, ekonomiści wolą proponować rekompensowanie przegranych niż protekcjonizm. Problem $\mathrm{z}$ rekompensowaniem polega na tym, że w większości wypadków jest to działanie albo niewystarczające, albo zostaje ono w ogóle zaniechane. Konsekwencje dystrybucyjne da się łagodzić poprzez wynagradzanie przegranych metodami systemów opieki i zabezpieczenia społecznego, redystrybucją ze środków pań- 
stwowego systemu podatkowego oraz działaniami na rzecz przekwalifikowania siły roboczej.

Wraz z rozpowszechnieniem się GŁW stało się oczywiste, że konkurencja zmieniła swoją postać. Obecnie zachodzi ona nie tyle pomiędzy towarami i firmami z poszczególnych krajów, ile pomiędzy poszczególnymi pracownikami na globalnym rynku pracy i toczy się o miejsca pracy (Baldwin, 2006). Relokacja zadań za granicę może nastąpić w każdej chwili. Głównymi cechami podzielonej globalnej produkcji stały się nagłość i nieprzewidywalność. Ponadto, postępująca robotyzacja zadań oraz ich przenoszenie za granicę, a następnie sprowadzanie z powrotem do kraju powodują gwałtowną zmianę typu pożądanych kwalifikacji w kierunku umiejętności pracy zespołowej, umiejętności cyfrowych, przystosowawczych, elastyczności oraz umiejętności uczenia się. Co więcej, nadejście cyfrowej łączności indywidualnej (face-to-face) będzie coraz bardziej zagrażać miejscom pracy osób wysoko wykwalifikowanych.

W związku z tym tradycyjny protekcjonizm chroniący konkretne branże gospodarki może okazać się niewystarczającym narzędziem, aby stawić czoła cyfryzacji i nowej globalizacji. Preferowaną reakcją powinno być raczej skupienie się na edukacji, uczeniu umiejętności uczenia się i kształtowaniu zdolności przystosowawczych. Obecnie kluczem do skutecznej polityki (re-)dystrybucji nie jest, jak dawniej, ochrona branż, lecz ochrona ludzi (Baldwin, 2006). Oprócz tego, jako że cyfryzacja i globalizacja przyczyniają się do zmniejszania udziału globalnych dochodów trafiających do pracowników, a więc pośrednio nasilają nierówności dochodowe w wielu krajach, kolejną pilną kwestią polityczną staje się również znalezienie środków zaradczych na te nierówności, co wykracza poza ochronę przegranych na globalizacji.

Jednakże, jak pokazują powyższe rozważania, wpływu globalizacji na sprawiedliwość społeczną często nie da się odróżnić od wpływu nowych technologii, ponieważ z punktu widzenia osoby zwolnionej nie ma żadnej różnicy pomiędzy tym czy jej miejsce pracy przejął robot, czy zrobili to pracownicy zagraniczni. W obydwu wypadkach doszło do utraty miejsca pracy i do okresowej, a być może nawet trwałej utraty dochodów. Natomiast tym, co odróżnia przemiany w handlu od innych przemian strukturalnych jest zagadnienie uczciwości. Rodrik (2017) twierdzi, że sama polityka redystrybucji nie wystarcza, aby stawić czoła wyzwaniom globalizacji: „Prowadzi nas to do innego społecznego i politycznego zarzutu wobec handlu: mianowicie, że handel narusza normy zakorzenione w naszych rozwiązaniach instytucjonalnych. Sugeruję tym samym, że handel może podkopywać interesy społeczne właściwe i istotne dla narodu, uznane i gwarantowane w jego prawie i przepisach. (...) Handel jest nie tylko stosunkiem rynkowym - jest również ingerencją w krajowe instytucje i narzę- 
dziem ich przekształcania ze szkodą dla niektórych grup”. W związku z tym Rodrik uważa za uzasadnione reagowanie na „dumping społeczny” (czyli np. sytuacje, w których konkurenci zagraniczni podcinają płace przez naruszanie praw pracowniczych swojej siły roboczej, ograniczając płace metodami politycznymi lub wykorzystując pracę przymusową itd.) w sposób analogiczny do tego, jak państwa reagują na zwyczajny „dumping cenowy”. Propozycja Rodrika sprowadza się zasadniczo do chronienia narodowej umowy społecznej instrumentami państwowej polityki antydumpingowej, a nie poprzez reakcje wielostronne.

Przeciwne stanowisko zajmuje Mario Draghi (2017), który opowiada się za reakcją wielonarodową na rzecz rozwiązania kwestii uczciwości (i jednocześnie bezpieczeństwa): „...współpraca wielostronna, prowadząca do konwergencji przepisów prawnych, stanowi warunek wstępny dla zaradzenia głębokim przyczynom tych niedomagań. Wykażę to, odwołując się do doświadczeń zarządzania otwartością w Unii Europejskiej. Odnośnie uczciwości, sprawa jest oczywista: ujednolicenie przepisów stanowi najsilniejszą gwarancję, że na całym wspólnym rynku europejskim zapewnione będzie równe pole gry. Właśnie z tego powodu po otwarciu granic wewnętrznych w Europie nastąpiło równoległe i jednoczesne wzmocnienie wspólnych, ponadnarodowych organów ustawodawczych i egzekucyjnych. Podobnie, tym, co sprawiło, że Jednolity Rynek przetrwał rozmaite kryzysy finansowe i związane z ochroną konsumentów była jego zdolność do przywracania bezpieczeństwa poprzez dostosowywanie przepisów wykonawczych i środków egzekucyjnych na całym obszarze".

Niemniej, europejska konwergencja w zakresie przepisów prawnych nie jest tylko atrakcyjnym narzędziem tworzenia w Europie równego i uczciwego pola gry. Jako przykład weźmy ostatnie doświadczenia z unijnym rozporządzeniem RODO. „The Economist” (22.09.2018, s. 13) stwierdza, że „zasady RODO są obecnie wykorzystywane jako wzorcowe praktyki w zakresie danych na wielu rynkach pozaeuropejskich". Unia Europejska ze swoim ogromnym wspólnym rynkiem jest w stanie użyć swoich kompetencji regulacyjnych do zwiększenia w oczach swoich obywateli legitymacji i uczciwości nie tylko integracji europejskiej, lecz także globalizacji. Wobec nowego oblicza globalnej gospodarki najważniejsze dziedziny skutecznego wpływania lub choćby przyczyniania się do realizacji wzorcowych praktyk w sferze regulacyjnej w skali globalnej z pewnością obejmują przeciwdziałanie uchylaniu się od podatków i korporacyjnemu „wyścigowi po najniższe podatki”, gwarancje praw pracowniczych, zapewnienie stabilności finansowej oraz inne wielostronne inicjatywy na rzecz regulacji globalnych finansów, handlu, inwestycji, know-how i obrotu danymi. Europa, która solidnie zajmie się tymi dziedzinami i naprawi je zarówno w ramach UE, jak i na całym kontynencie, ustanawiając tym samym globalny wzorzec dbałości o uczci- 
wość w stosunkach wielostronnych, może przyczynić się znacząco do tego, że globalizacja stanie się nie tylko uczciwa, bezpieczna i sprawiedliwa, lecz także trwała i długofalowo akceptowalna.

Europa, która za priorytet w zakresie sprawiedliwości uzna ludzi i poważnie zajmie się kwestiami uczciwości, tak na kontynencie, jak i na szczeblu międzynarodowym, podejmując kluczowe kwestie, które ludzi drażnią i niepokoją, osiągnie widoczne efekty z pewnością dostrzegalne dla europejskich wyborców.

\subsection{Rządy europejskie}

\subsubsection{Europejski trylemat polityczny}

Na jakim szczeblu winny być podejmowane decyzje? Co powinno pozostać w gestii państwa narodowego, a co należy przekazać na szczebel ponadnarodowy - delegując czy to do Unii Europejskiej, czy do globalnych instytucji wielonarodowych, takich jak WTO? Rodrik (2011) jest zdania, że w tym kontekście pojawia się „trylemat globalizacji”, który zmusza twórców polityki do dokonania wyboru pomiędzy hiperglobalizacją, podejmowaniem decyzji na szczeblu narodowym i polityką demokratyczną (zob. rys. 5).

Rysunek 5. Trylemat globalizacji Rodrika (w którym wybrać można tylko dwa rozwiązania)

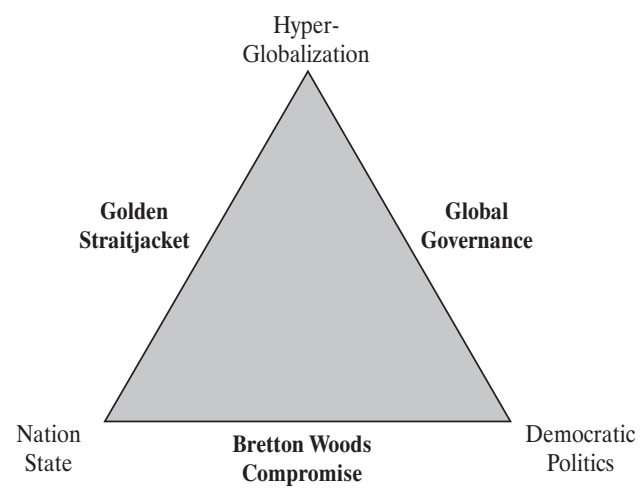

Źródło: diagram na podstawie: Rodrik, 2011, s. 201.

Argument podstawowy mówi, że nadmierna globalizacja potrzebuje globalnych rządów opartych na demokratycznej legitymacji. Alternatywnie, jeżeli państwa nie są skłonne odstąpić części swojej suwerenności przez jej przekazanie instytucjom ponadnarodowym, stracą demokratyczną kontrolę w obliczu hiperglobalizacji, a wtedy znajdą się praktycznie na łasce „mechanizmów” ryn- 
kowych. Przykładowo, parytet złota wymuszał stosowanie w razie konieczności automatycznych korekt. Doświadczenia z początku XX w. z automatycznymi (deflacyjnymi) korektami były katastrofalne, jako że młode demokracje i rosnące w siłę ruchy robotnicze nie chciały zaakceptować niezwykle wysokiego poziomu bezrobocia jako narzędzia pobudzania deflacji płac. Podobnie, próby zastosowania deflacji płac i cen w celu przywrócenia konkurencyjności w kilku krajach w okresie kryzysu strefy euro wywołały masowe bezrobocie i zagroziły tkance społecznej w krajach dotkniętych kryzysem. Z kolei - jak sugeruje omawiany trylemat - zachowanie kompetencji decyzyjnych na szczeblu państwa narodowego wymaga ograniczania hiperglobalizacji.

Czy Unia Europejska, jawnie dążąca do ujednolicenia norm prawnych na całym swoim obszarze, nie jest lepiej przygotowana do realizacji tych zadań w kontekście europejskiej integracji ekonomicznej? Benoît Cœuré (2017), członek zarządu Europejskiego Banku Centralnego (EBC), następująco komentuje trylemat Rodrika: „...doświadczenia europejskie pokazują, że te kompromisy dadzą się zrealizować. Możliwy jest wariant globalizacji oparty na szczątkowym szkielecie przepisów międzynarodowych szczebla wspólnotowego, który pozostawi swobodę manewru rządom krajowym. Zasadę subsydiarności, silnie zakorzenioną w postanowieniach Traktatu o Unii Europejskiej, można faktycznie interpretować jako regionalną próbę rozwiązania trylematu Rodrika. Jej celem jest zapewnienie, aby decyzje w jak największym stopniu podejmowane były na korzyść obywatela i aby działania na szczeblu europejskim inicjowane były tylko wtedy, kiedy danych celów nie da się zadowalająco osiągnąć na szczeblu krajowym, regionalnym lub nawet lokalnym".

Z niniejszych rozważań wynika konieczność rozwiązania dwóch istotnych problemów. Po pierwsze, trylemat Rodrika może być obecny w niektórych, ale nie wszystkich aspektach „globalizacji”. Dlatego ważne jest ustalenie, na jakim szczeblu najsłuszniej jest podejmować dane decyzje, uzależniając to od konkretnych kwestii, których decyzje te dotyczą. Po drugie, wszystkie decyzje przekazywane na poziom ponadnarodowy wymagają pewnej formy legitymizacji demokratycznej.

\subsubsection{Obszary polityki w Europie - jak przywrócić równowagę?}

Kwestia optymalnej alokacji polityki, czyli powierzenia jej poszczególnych obszarów w gestie różnych szczebli nie jest zagadnieniem nowym. Jej podstawy teoretyczne można znaleźć w klasycznych pozycjach na temat integracji europejskiej, takich jak książka Baldwina i Wyplosza (2012) pod nagłówkiem „teoria federalizmu fiskalnego". Zgodnie z tą teorią, podejmowanie decyzji należy dele- 
gować na szczebel ponadnarodowy tylko wtedy, gdy korzyści z takiego rozwiązania przeważają nad kosztami pozbawienia się części suwerenności. W przeciwnym razie decyzje lepiej jest podejmować na szczeblu krajowym lub nawet lokalnym. I rzeczywiście, ulokowanie kompetencji decyzyjnych na najniższym możliwym szczeblu bez rezygnacji z korzyści netto stanowi sam rdzeń zasady subsydiarności. Poważne korzyści płynące z regulacji ponadnarodowej wynikają z efektów skali i zysków ubocznych, jednak muszą one być zrównoważone przez preferencje krajowe, które stanowią „koszty”.

Zaczynając od kwestii sprawiedliwości, nie ulega wątpliwości, że rozwiązywanie problemów dystrybucyjnych w celu stabilizowania tkanki społecznej kraju jest w największej mierze zadaniem państw narodowych. Państwa członkowskie UE nadal różnią się od siebie dość wyraźnie pod względem krajowych preferencji w zakresie redystrybucji i instytucji państwowych systemów socjalnych. Próżno oczekiwać, że w przewidywalnym czasie upodobnią się one do siebie na tyle, by taka konwergencja umożliwiała zastosowanie w tej dziedzinie odgórnych kompetencji europejskich. Jeżeli jednak pozostawiamy kwestie redystrybucji na szczeblu państw narodowych, to pojawiają się trzy poważne zastrzeżenia. Po pierwsze, przemiany strukturalne wywołują o wiele mniejsze zawirowania w środowisku makroekonomicznym, przyjaznym wobec zatrudnienia, które często pozostaje poza pełną władzą rządów narodowych. Szczególnie w strefie euro ważnymi zagadnieniami, które należy koniecznie brać pod uwagę, są niemal całkowita nieobecność mechanizmu transferów fiskalnych oraz koordynacja polityki ostrożnościowej w skalach mikro i makro. Drugie zastrzeżenie dotyczy umów handlowych, które negocjowane są na szczeblu wspólnotowym, ale często mają różny wpływ na poszczególne kraje członkowskie, które z tego powodu domagają się takiego lub innego mechanizmu transferowego ${ }^{8}$. Trzecim są strategie uchylania się od podatków, stosowane tak w skali europejskiej, jak i globalnej, ograniczając zasoby dostępne na potrzeby redystrybucji - ten problem można próbować skutecznie rozwiązać tylko na szczeblu ponadnarodowym.

Poważnym argumentem na rzecz wyższości rządów wspólnotowych jest europejski jednolity rynek, będący źródłem silnych efektów skali. Oczywiście, czasami krajowe preferencje przemawiają przeciw normom produktowym UE itd.,

8 W 2007 r. UE powołała Europejski Fundusz Dostosowania do Globalizacji (EGF), aby z jego środków współfinansować przywracanie na rynek pracy pracowników, którzy negatywnie odczuli skutki globalizacji. EGF był od początku niedofinansowany - jako pułap jego środków ustalono ok. $0,1 \%$ budżetu UE, a w dodatku ponad $50 \%$ gromadzonych funduszy przeznacza się na łagodzenie konsekwencji makroekonomicznych kryzysu finansowego. Gruntowna analiza na ten temat - zob. Claeys i Sapir (2018). 
ale ogólnie biorąc, korzyści w tym zakresie zdecydowanie górują nad kosztami zrzeczenia się części suwerenności. Jednak bilans kosztów i korzyści nie jest dany raz na zawsze. Na przykład, zwłaszcza w czasach napięć ekonomicznych po ŚKF, zasada „swobodnego przepływu osób”, będąca jedną ze swobód jednolitego rynku, wywołała silne tarcia i uznana została za jeden z czynników wpływających na brytyjską decyzję o brexicie. Właśnie dlatego negocjacje pomiędzy Unią a Wielką Brytanią obracają się wokół (nie-)możliwości uzgodnienia swobodnego dostępu do jednolitego rynku z wyłączeniem swobodnego przepływu osób. W chwili pisania niniejszego artykułu Komisja UE zdecydowanie wyklucza takie rozwiązanie.

Zupełnie inaczej jest ze wspólną polityką zagraniczną, obronną, migracyjną i kwestią ochrony granic zewnętrznych Unii - w tych dziedzinach wspólnota daje ogromne korzyści, jednak dotyczące ich preferencje krajowe były w przeszłości tak skrajnie różne, że obszary te w znacznej mierze pozostały w gestii państw narodowych. Obecnie - przynajmniej w niektórych, jeśli nie wszystkich wymienionych dziedzinach - szybko zmieniająca się sytuacja geostrategiczna coraz wyraźniej przesuwa punkt ciężkości w stronę rządów europejskich.

Istnieją jednak inne ważne obszary, w których przywrócenie równowagi w zakresie rządów jest niezbędne. Dotyczy to przede wszystkim Unii Gospodarczej i Walutowej (UGW). Obecnie panuje ogólna zgoda co do tego, że UGW w postaci zaprojektowanej postanowieniami traktatu z Maastricht z roku 1992 jest unią walutową o poważnych niedomaganiach. Była ona faktycznie próbą stworzenia unii monetarnej bez unii bankowej i bez żadnych mechanizmów transferów fiskalnych. Tymczasem skuteczna obrona przed skutkami wstrząsów asymetrycznych w ramach unii walutowej wymaga posiadania adekwatnych mechanizmów rozkładania ryzyka. Przekładając to na język trylematu Rodrika, oznacza to, że dla dalszego funkcjonowania i trwałości UGW konieczna jest rezygnacja państw członkowskich z części suwerenności w niektórych obszarach (Sander, 2011). Na temat tego, co konkretnie jest niezbędne, można się spierać, niemiej widoczna jest coraz powszechniejsza zgoda co do tego, że oprócz pewnego rodzaju narzędzi podziału ryzyka fiskalnego (np. poprzez Europejski Mechanizm Stabilizacyjny - EMS), decydujące znaczenie ma uzupełnienie europejskiej unii bankowej przez wprowadzenie Europejskiego Systemu Ubezpieczenia Depozytów Bankowych (EDIS) (zob. np. Bénassy-Quéré i in., 2018)99. W innych dziedzinach, a zwłaszcza w odniesieniu do „fiskalnego kaftana bez-

9 Jednakże - jak wynika z trwającej obecnie debaty w sprawie EDIS - emocje i postawy narodowe niejednokrotnie sprzeciwiają się wprowadzeniu regulacji przynoszących korzyści netto. Poważną przeszkoda dla tego projektu są obecnie szczególnie niemieckie opory przeciw postrzeganemu ryzyku „uwzajemnienia długów”. 
pieczeństwa" nakładanego przez Europejski Pakt Stabilności i Wzrostu, mówi się o tym, że być może wskazana jest „renacjonalizacja” polityki fiskalnej w celu „przywrócenia rządom narodowym kontroli” nad - i trzeba tu dodać: również odpowiedzialności za sposób wykorzystania wpływów podatkowych (Eichengreen i Wyplosz, 2016) ${ }^{10}$. Trudno zaprzeczyć, że rządy te zostały w tym celu wybrane i za te sprawy odpowiadają one przed swoimi wyborcami. Inaczej mówiąc, rządy w strefie euro wymagają przywrócenia równowagi - nie tylko po to, by zapewnić trwałość funkcjonowania UGW, lecz także, by stawiać czoła wzbierającej fali antywspólnotowego populizmu (Sander, 2016).

Wreszcie, na szczeblu europejskim (i nie tylko) pojawiło się też nowe, ważne i nabierające znaczenia zadanie rozwiązania problemów, jakie niesie ze sobą cyfryzacja i firmy superstar. W tym kontekście rysują się dwa główne obszary wspólnych działań.

Po pierwsze, zasadnicze znaczenie ma posiadanie i prowadzenie wspólnej europejskiej polityki przemysłowej. UNCTAD (2018, s. 128) informuje: „W ciągu dekady, jaka minęła od światowego kryzysu finansowego, dramatycznie wzrosła liczba krajów, które wprowadzają własne, krajowe strategie rozwoju przemysłowego. (...) Kraje na różnych poziomach rozwoju stosują dziś celowe strategie przemysłowe, nakierowane nie tylko na rozwój gospodarczy, lecz mające również zapewniać reagowanie na wszelkiego rodzaju wyzwania naszych czasów. Wśród wyzwań takich można wymienić np. tworzenie miejsc pracy i zmniejszanie skali ubóstwa, uczestnictwo w rewolucji technologicznej i w globalnych łańcuchach wartości (GŁW), promowanie produkcji wydajnej, czystej energii i ogólnie gospodarki bardziej przyjaznej dla środowiska". O ile polityki te są często projektowane na szczeblu krajowym, można podać co najmniej dwa argumenty przemawiające za wyższością śmiałej strategii europejskiej w tych dziedzinach. Po pierwsze, globalizacja i cyfryzacja wykazują nierównomierny wpływ na jednolitym rynku europejskim - bardziej niekorzystny zwłaszcza w południowych krajach członkowskich, czemu można by skuteczniej zaradzić narzędziami wspólnotowymi. Po drugie, firmy superstar mają zasięg globalny, ale są głęboko zakotwiczone w swoich krajach pochodzenia, co sugeruje, że dla rozwijania takich branż ważne są warunki krajowe w zakresie wielkości rynku, zaplecza gospodarczego i surowców, jak również zachęt politycznych. Jednolity rynek europejski ma zatem co prawda decydujące znaczenie pod tym względem, ale potrzebuje również uzupełnienia w postaci jednolitego rynku cyfrowego oraz działalności w zakresie wiedzy i doświadczenia, słowem

10 Eichengreen i Wyplosz (2016) twierdzą, że renacjonalizacja polityki fiskalnej wymaga rozwiązania problemu nawisów zadłużeniowych oraz wprowadzenia wiarygodnych przepisów wykluczających pomoc dla przedsiębiorstw zagrożonych upadłością. 
- czegoś w rodzaju Inicjatywy dotyczącej Europejskich Szkół Wyższych. Faktem jest, że inicjatywy takie już istnieją, ale dla ich naprawdę skutecznego działania potrzeba jeszcze odpowiedniej skali ich działań i chęci do przekazywania zasobów za granicę.

Wreszcie, jak już wspomniano, regulacje europejskie można wykorzystać do ustanawiania lub przynajmniej wpływania na globalne normy na obecnie zdecydowanie niedoregulowanych rynkach cyfrowych, co może ostatecznie pomóc Europie w wypracowaniu i kształtowaniu przewag konkurencyjnych w branżach cyfrowych.

\subsubsection{Ku silniejszej legitymacji demokratycznej rządów europejskich}

Rozważana te prowadzą nas do kwestii legitymacji demokratycznej dla procesów decyzyjnych przekazanych na szczebel ponadnarodowy. W tym kontekście najpoważniejszy problem polega na tym, że większość decyzji podejmowana jest na szczeblu międzyrządowym, najczęściej w oparciu o propozycje przygotowane przez Komisję Europejską. Parlament Europejski ma w tych kwestiach pewien udział, ale niewielki, zależnie od konkretnej sprawy. Dlatego legitymacja demokratyczna przeważnie wywodzi się, pośrednio, z wyborów krajowych. To z kolei oznacza, że krajowym wyborcom najczęściej trudno jest prześledzić jakikolwiek związek nowych regulacji z tym, na kogo oddali oni głos przy urnie wyborczej. Czy zatem Europa potrzebuje gruntownej reformy swojej struktury i procedur decyzyjnych w obliczu nowej ekonomii globalnej?

Utrzymanie strategii ,jak gdyby nigdy nic" z jedynie drobnymi korektami wydaje się szczególnie niebezpieczne w obliczu narastającej fali postaw i emocji antywspólnotowych i populistycznych w krajach Unii Europejskiej. Komisja Europejska z pewnością zdaje sobie z tego sprawę. W „Białej Księdze o Przyszłości Europy” (European Commission, 2017) Komisja zestawia pięć różnych scenariuszy. Są to: 1) „kurs dotychczasowy”, czyli dalszy stopniowy postęp w kierunku ,jeszcze ściślejszej unii”; 2) „nacisk na jednolity rynek”, czyli bierne reagowanie na różnice w zakresie preferencji; 3) „kto chce, niechaj robi więcej”, co oznacza dopuszczenie Europy różnych prędkości, również postępującej w kierunku jeszcze ściślejszej unii; 4) koncentracja na wybranych obszarach polityki i na „większej wydajności w załatwianiu spraw”, co może oznaczać nową listę priorytetów, zapewne po dogłębnym rozważeniu kosztów i korzyści; 5) „zróbmy więcej wspólnie”, co z kolei oznacza przyśpieszenie rozwoju ku ściślejszej unii. Chociaż wniesienie przyczynku do analizy procesu przywracania w Europie równowagi w świetle pięciu wymienionych scenariuszy wykracza poza ramy niniejszego studium, omówimy poniżej trzy kwestie w kontekście wspo- 
mnianego wyżej podwójnego wyzwania, niesionego przez globalizację i cyfryzację.

Po pierwsze, istnieje wiele oczywistych obszarów, w których korzyści z czysto ekonomicznego punktu widzenia są olbrzymie: na przykład jednolity rynek o otwartych granicach wewnętrznych, w których europejskie łańcuchy wartości z łatwością zachowują konkurencyjność11; europejska strategia cyfrowa, wykorzystująca dźwignię jednolitego rynku, aby sięgnąć swoimi regulacjami poza Europę; działania na rzecz rozwiązania problemu uchylania się od podatków; promowanie przepisów mających gwarantować stabilność finansową; tworzenie europejskiej przestrzeni wiedzy; wspólnotowe inwestycje w infrastrukturę transportu i komunikacji i szereg innych.

Po drugie, przewagi wynikające ze współpracy są mniej wyraźne w innych dziedzinach, szczególnie w związku z UGW. W istocie, dziś jest sprawą mocno kontrowersyjną czy pierwotny cel i intencje traktatu z Maastricht $\mathrm{w}$ tym zakresie są nadal aktualne. Wątpliwości takie prowadzą nas do kwestii scenariuszy: jeszcze ściślejsza unia, czy Europa różnych prędkości, a może Europa wielotorowa? W pierwszym wypadku wszystkie kraje zobowiązane są do wspólnego dążenia do większej integracji we wszystkich dziedzinach (zgodnie z intencją traktatu). Jednak to jest de facto tylko złudzeniem, bo przecież nie wszystkie kraje członkowskie Unii przystąpiły do dziś do UGW czy też do obszaru Schengen. Można by już dzisiaj postrzegać UE jako unię dwóch prędkości, w której kraje członkowskie UGW stanowią szybko integrującą się czołówkę, a reszta podąża w tyle. Nie wolno przy tym tracić z pola widzenia faktu, że również nie wszystkie kraje członkowskie UGW są gotowe lub chętne do wejścia na szybki tor. W rzeczywistości UE już obecnie jest Europą niejednorodną i to nie dwóch, lecz raczej wielu prędkości. Co więcej, są w niej kraje, które wcale nie podzielają pierwotnej wizji traktatowej, skoro wolą pozostawać poza UGW lub poza Schengen. W tym kontekście słuszniej byłoby mówić o Europie wielu torów, a problemem takiej wielotorowości jest ryzyko, że członkowie zechcą wydłubywać rodzynki z ciasta, czyli z całości wybierać to, co im najbardziej odpowiada. Ryzyko takie należy akceptować i wyważyć względem innego zagrożenia, mianowicie wzrostu niechęci lub nawet sprzeciwu wobec dalekiej ingerencji rządów europejskich, zwłaszcza w nowych państwach członkowskich. W każdym razie

11 Nie wymieniłem tu takich dziedzin, jak migracje, bezpieczeństwo i polityka zagraniczna, ponieważ nie wchodzą one w zakres zainteresowań niniejszego studium. Niemniej, ażeby pozbawiona granic wewnętrznych strefa Schengen mogła bez przeszkód funkcjonować, konieczna może się okazać skuteczniejsza, a więc realizowana wspólnie kontrola granic zewnętrznych, przy czym w kontekście niniejszych rozważań argument ten opieramy na przesłankach czysto ekonomicznych. 
atrakcyjność uczestnictwa w większej liczbie lub nawet we wszystkich sferach integracji europejskiej $\mathrm{w}$ ramach porządku wielotorowego zasadniczo zależy od „legitymizacji wyników”. Jak pokazaliśmy powyżej, istnieje wiele dziedzin, w których europejskie wspólnotowe działania polityczne pozwalają znacznie lepiej radzić sobie z wyzwaniami globalizacji w porównaniu z poprzestaniem na polityce czysto krajowej w świecie firm superstar i wschodzących nowych superpotęg, takich jak Chiny. Jeżeli Europa ma funkcjonować skutecznie, to porządek wielotorowy nie może stanowić zagrożenia dla integracji europejskiej - przeciwnie, powinien on wspierać integrację zawsze i wszędzie tam, gdzie jest to konstruktywne i korzystne.

Po trzecie i ostatnie, niezbędna jest „legitymizacja wkładu”. Debata o legitymacji demokratycznej dla europejskich procesów decyzyjnych jest złożona i obraca się wokół wzmocnienia kompetencji Parlamentu Europejskiego. W kontekście tym pojawia się wiele propozycji, których dokładniejsze omówienie dalece wykracza poza ramy niniejszego studium. Tutaj należy jedynie odnotować, że propozycje reform zależą zasadniczo od tego, jakie stanowisko zajmuje się względem prędkości integracji - jednej versus wielu - oraz jej porządku: jedno- lub wielotorowego. Przykładowo, zespół skupiony wokół francuskiego ekonomisty Thomasa Piketty'ego, o postawie proeuropejskiej zaleca wzmocnienie kompetencji Parlamentu Europejskiego oraz utworzenie "Zgromadzenia strefy euro" (Hennette i in., 2017). Z kolei Eichengreen (2018) krytykuje takie podejście jako rozwiązanie w najlepszym razie niepełne, bo oparte - jego zdaniem - na przestarzałej wizji Europy dwuprzęsłowej, w której strefa euro stanowi przęsło główne. Badacz ten proponuje coś innego: wyposażyć istniejący Parlament Europejski w kompetencje proporcjonalnie do tego, które państwa członkowskie uczestniczą w których strefach, instytucjach i politykach Wspólnoty w ramach wielotorowej Europy. Na przykład, członkowie parlamentów krajów strefy euro głosują w sprawach tejże, przedstawiciele krajów strefy Schengen w sprawach dotyczących Schengen i tak dalej. W ten sposób Eichengreen (2018) liczy na to, że „Parlament stałby się przekaźnikiem woli ludzi i umożliwiłby im demokratyczną kontrolę w tym sensie, że technokraci z Komisji, z EBC, i z innych instytucji UE byliby przed nimi demokratycznie odpowiedzialni - z tym, że głos i kontrolę zyskaliby nie wszyscy, lecz ludzie właściwi to jest obywatele tych krajów, które zgodziły się scedować w danym zakresie swoje narodowe prerogatywy". Jak również - co Eichengreen dodaje pod koniec swojej książki - rozwiązanie takie mogłoby ostatecznie nawet pomóc w powstrzymaniu fali populizmu antyeuropejskiego wzmagającej się na kontynencie. 


\section{Europejska agenda polityczna w i na rzecz nowej ekonomii globalnej}

Europa stoi w obliczu potrójnego wyzwania - odnalezienia się w dobie globalizacji, cyfryzacji oraz przybierających na sile postaw antyeuropejskich w Unii i populizmu w innych krajach. Czynnikiem, który sprawia, że wyzwaniom tym jest tak trudno sprostać są ich głębokie i zawiłe współzależności. Nowe technologie napędzały proces globalizacji dawniej i będą napędzać go nadal, choć zmieni się charakter tego wpływu. Konsekwencje socjoekonomiczne tych procesów są złożone i powiązane, a polityka nie zajmuje się nimi w stopniu dostatecznym, co zwiększa niepewność ekonomiczną w wielu krajach Europy i coraz poważniej zagraża stabilności jej klasy średniej.

Jednakże w wielu sytuacjach zjednoczona Europa lepiej niż małe państwa narodowe jest przygotowana do pokonania problemów, jakie niesie ze sobą globalizacja i globalne firmy superstar. Przede wszystkim, wspólnota jest w stanie wykorzystać swój olbrzymi jednolity rynek, by wpływać na ukształtowanie takiej globalnej agendy, w której ludzie stawiani będą na pierwszym miejscu w porządku globalnych spraw ekonomicznych. W ten sposób można doprowadzić do ustalenia lepszych globalnych przepisów regulujących biznes cyfrowy, prawa pracownicze, stabilność finansową, inwestycje transgraniczne, przepływ wiedzy i inne dziedziny.

Niemniej, warunkiem, od którego wszystko to zależy jest silna, funkcjonalna Unia Europejska o mocniejszej legitymacji demokratycznej. Maksyma Jeana Monnet: „L'Europe se fera dans les crises et elle sera la somme des solutions apportées à ces crises" [Europa wykuwać się będzie w kryzysach i stanowić będzie sumę rozwiązań, jakie wypracuje, by kryzysy te pokonać ] zapewne sprawdzała się w przeszłości. W świecie zglobalizowanym, cyfrowym, pozbawionym łagodnego i dobroczynnego hegemona, gwaranta światowego porządku ekonomicznego opartego na zestawie jasnych i wspólnych regul, Europa musi podjąć się nowej roli - roli jednej z trzech superpotęg. Jeżeli Europa ma mieć zdolność faktycznego współkształtowania przyszłości globalnej gospodarki, musi zdecydować się na działanie i wykonać duży, pewny krok naprzód, nie czekając na kryzysy i nie poprzestając na wydobywaniu się z nich.

Europa potrzebuje przebudzenia. Musi działać proaktywnie w trzech dziedzinach naraz: wzmacniać metodami demokratycznymi legitymizację prowadzonej przez siebie polityki, osiągać dobre wyniki w zakresie stanu majątku, prosperity mieszkańców i stabilności oraz wziąć na siebie globalną odpowiedzialność za gospodarkę światową - po to, by nowa ekonomia globalna stała się lepszym środowiskiem do pracy i do życia. 


\section{Bibliografia}

Acemoglu, D. i Restrepo, P. (2018). Modeling automation. American Economic Review Papers and Proceedings, 108, 48-53.

Autor, D., Dorn, D., Katz, L.F., Patterson, C. i Van Reenen, J. (2018). The fall of the labor share and the rise of superstar firms. MIT mimeo updated from NBER Working Paper.

Baldwin, R. (2006). Globalization: The great unbundling(s). Prime Minister's Office: Economic Council of Finland. Eu2006.fi.

Baldwin, R. (2016). The great convergence: Information technology and the new globalization. Cambridge, MA.: Harvard University Press.

Baldwin, R. i Wyplosz, C. (2012). The economics of European integration. $4^{\text {th }}$ edition. Maidenhead: McGraw-Hill.

Bénassy-Quéré, A. i in. (2018). Reconciling risk sharing with market discipline: A constructive approach to euro area reform. CEPR Policy Insight 91, January. London: CEPR.

Claeys, G. i Sapir, A. (2018). The European globalisation adjustment fund: Easing the pain from trade? Bruegel Policy Contribution 5. Brussels: Bruegel.

Couré, B. (2017). Sustainable globalization: Lessons from Europe. Speech at the Workshop "Financial globalization and its spillovers - monetary and exchange rate policy in times of crises". Special public event "25 years after Maastricht: The future of money and finance in Europe", February 16. Maastricht. Acquired from: https://www.ecb.europa. eu/press/key/date/2017/html/sp170216.en.html.

Constantinescu, C., A. Mattoo i Ruta, M. (2017). Trade developments in 2016: Policy uncertainty weighs on world trade. February 21. Washington DC: World Bank Group.

Draghi, M. (2017). Sustaining openness in a dynamic global economy. Speech at the Economic Policy Symposium of the Federal Reserve Bank of Kansas City, Jackson Hole, 25 August. Acquired from: https://www.ecb.europa.eu/press/key/date/2017/html/ecb.sp170825.en.htm.

Eichengreen, B. (2018). The populist temptation: Economic grievance and political reaction in the modern era. Oxford: Oxford University Press.

Eichengreen, B. i Wyplosz, C. (2016). Minimal conditions for the survival of the Euro. In: Baldwin, R. and F. Giavazzi (eds.). How to fix Europe's monetary unions: Views from leading economists. London: A VoxEU.org eBook. CEPR.

European Commission. (2017). White paper and the future of Europe: Reflections and scenarios for the EU27 by 2015. Brussels: European Commission.

Funke, M., Schularick, M. i Trebesch, C. (2015). Going to extremes: Politics after financial crises, 1870-2014. CESifo Working Paper No. 5553. October.

Guiso, L., H. Herrera, M. Morelli, M. i Sonno, T. (2018). Global crises and populism: The Role of Eurozone institutions". EIEF Working Papers Series 1806. Rome: Einaudi Institute for Economics and Finance.

Hennette, S., Piketty, T., Sacriste, G. i Vauchez, A. (2017). Pour un traité de démocratisation de l'Europe. Paris: Editions du Seuil.

IMF. (2017). World Economic Outlook April 2017. Washington DC: International Monetary Fund.

IMF. (2018). World Economic Outlook April 2018, Chapter 4. Washington DC: International Monetary Fund.

Lakner, C. i Milavonic, B. (2013). Global income distribution: from the fall of the Berlin Wall to the great recession. The World Bank. Policy Research Working Paper 6719, December. Washington DC: World Bank. 
Lane, P.R. i Milesi-Ferretti, G.M. (2017). International Financial Integration in the Aftermath of the Global Financial Crisis. IMF Working Paper WP/17/115. Washington DC: International Monetary Fund.

Marin, D., Veugelers, R. i Felia, J. (2017). A revival of manufacturing in Europe. Recent evidence about reshoring. In: Veugelers, R. (ed.), Remaking Europe: The new manufacturing as an engine of growth (p. 102-125). Bruegel Blueprint Series 26. Brussels: Bruegel.

McCauley, R. (2011). De-internationalizing global banking? Comparative Economic Studies, 56(2), June, 257-270.

McCauley, R., Bénétrix, A.S., McGuire, P.M. i von Goetz, P. (2017). Financial deglobalisation in banking? Trinity Economic Papers No. 1717, July. Dublin: Trinity College.

Nordhaus, W.D. (2015). Are we approaching an economic singularity? Information technology and the future of economic growth. Cowles Foundation Discussion Paper No. 2021. New Haven, CT: Cowles Foundation.

Rodrik, D. (2011). The globalization paradox. Democracy and the future of the world economy. New York and London: W.W. Norton \& Co.

Rodrik, D. (2017). It's time to think yourself on free trade. Foreign Policy, January 27. Acquired from: https://foreignpolicy.com/2017/01/27/its-time-to-think-for-yourself-onfree-trade/.

Sander, H. (2011). Europe must grapple with the debt crisis now. The Conversation: Global Perspectives. May 18. Acquired from: https://theconversation.com/europe-must-grapplewith-debt-crisis-now-1264.

Sander, H. (2016). Renationalising fiscal policy would help rebuild support for the EU. EUROPP Blog: European Politics and Policy. London School of Economics and Political Science. Acquired from: http://bit.ly/2bAYUYx.

UNCTAD. (2017). World Investment Report 2017. Geneva: United Nations Conference on Trade and Development.

UNCTAD (2018). World Investment Report 2018. Geneva: United Nations Conference on Trade and Development.

Tørsløv, T., Wier, L. i Zucman, G. (2018). The missing profit of nations. NBER Working Paper 24791. Cambridge, MA: NBER.

Van Reenen, J. (2018). Increasing differences between firms: Market power and the macroeconomy. Economic Policy Symposium of the Federal Reserve Bank of Kansas City, Jackson Hole, 29 July.

Williamson, J. (1990). What Washington means by policy reform. In: J. Williamson, (ed.): Latin American readjustment: How much has happened. Washington DC: Institute for International Economics. 